NBER WORKING PAPER SERIES

\title{
FURTHER RESULTS ON MEASURING THE WELL-BEING OF THE POOR USING INCOME AND CONSUMPTION
}

\author{
Bruce D. Meyer \\ James X. Sullivan \\ Working Paper 13413 \\ http://www.nber.org/papers/w13413
NATIONAL BUREAU OF ECONOMIC RESEARCH
1050 Massachusetts Avenue
Cambridge, MA 02138 \\ September 2007
}

We thank Kerwin Charles, Sheldon Danziger, Kara Kane, and Paula Worthington for extremely helpful comments. We also thank Wallace Mok for excellent research assistance. The views expressed herein are those of the author(s) and do not necessarily reflect the views of the National Bureau of Economic Research.

(C) 2007 by Bruce D. Meyer and James X. Sullivan. All rights reserved. Short sections of text, not to exceed two paragraphs, may be quoted without explicit permission provided that full credit, including (c) notice, is given to the source. 
Further Results on Measuring the Well-Being of the Poor Using Income and Consumption Bruce D. Meyer and James X. Sullivan

NBER Working Paper No. 13413

September 2007

JEL No. D31,I31,I32,I38

\begin{abstract}
$\underline{\text { ABSTRACT }}$
In the U.S., analyses of poverty rates and the effects of anti-poverty programs rely almost exclusively on income data. In earlier work (Meyer and Sullivan, 2003) we emphasized that conceptual arguments generally favor using consumption data to measure the well-being of the poor, and, on balance, data quality issues favor consumption in the case of single mothers. Our earlier work did not show that income and consumption differ in practice. Here we further examine data quality issues and show that important conclusions about recent trends depend on whether one uses consumption or income. Changes in the distribution of resources for single mothers differ sharply in recent years depending on whether measured by income or consumption. Measures of overall and sub-group poverty also sharply differ. In addition to examining broader populations and a longer time period, we also consider new dimensions of data quality such as survey and item nonresponse, imputation, and precision. Finally, we demonstrate the flaws in a recent paper that compares income and consumption data.
\end{abstract}

Bruce D. Meyer

Harris School of Public Policy

University of Chicago

1155 E. 60th Street

Chicago, IL 60637

and NBER

bdmeyer@uchicago.edu

James X. Sullivan

Department of Economics

and Econometrics

447 Flanner Hall

University of Notre Dame

Notre Dame, IN 46556

James.X.Sullivan.197@nd.edu 


\section{Introduction}

Conceptual arguments generally favor consumption for measuring well-being. Consumption is a better measure of the long run resources available to the family (their permanent income) than annual income. Income measures fail to capture differences across families and over time in the accumulation of assets or access to credit. Also, consumption is more likely to reflect private and government transfers and the insurance value of government programs. Nevertheless, poverty and inequality in the U.S. are almost exclusively measured using annual income. Income is also the primary measure used to study the effects of anti-poverty programs. ${ }^{1}$

In earlier work (Meyer and Sullivan, 2003) we emphasized the conceptual and measurement advantages of consumption over income. However, we did not show that the choice between income and consumption matters in practice for important outcomes. This paper shows that the choice between income and consumption matters when measuring the well-being of the disadvantaged. We compare income data from the Current Population Survey (CPS) — the official source of income and poverty data in the U.S. - to consumption data from the Consumer Expenditure (CE) Survey - the most comprehensive source of expenditure data. We find a substantial drop in income in the bottom decile of single mothers while their consumption rises moderately. The patterns are similar in two income and two consumption datasets. We find that $\mathrm{CE}$ Survey and CPS income at the very bottom are remarkably similar in levels and changes. These results are important because recent authors have emphasized these income

\footnotetext{
${ }^{1}$ Exceptions include Cutler and Katz (1991), Gruber (1997, 2000), Slesnick (1992, 1993, 2001), Krueger and Perri (2006), Jencks, Mayer, and Swingle (2004b), Johnson, Smeeding and Torrey (2005), Johnson (2004), DeLeire and Levy (2006), Kaushal, Gao, and Waldfogel (2006), and Meyer and Sullivan (2003, 2004, 2006a,b, 2007).
} 
patterns and used them to evaluate welfare reform (Blank and Schoeni 2003; Murray and Primus 2005). Also, for those 65 and older, income poverty over the past two decades falls by 28 percent, while consumption poverty falls by more than half. Deep poverty and poverty gaps for the U.S. fall sharply when measured using consumption but remain flat or rise when measured with income.

We present further evidence that consumption is measured better than income at the bottom of the distribution. Our earlier work emphasized the case of single mothers while here we show that the results are much broader. We also discuss new dimensions to data quality including nonresponse, imputation, and the precision of estimates. The bottom deciles of consumption exceed those for income, suggesting under-reporting of income. There is a high and rising under-reporting rate for government transfers, a source of income that is particularly important at the bottom. In addition, the nonresponse and imputation rates are similar or higher in the CPS than in the CE Survey. We also document the degree of under-reporting of consumption in the CE Survey, as well as show that the speculation regarding possible bias due to attrition in the CE Survey data is unfounded. Finally, low consumption for the worst off among the disadvantaged seems to be more closely associated with other bad outcomes than is low income. On the other hand, available consumption data sources have much smaller sample sizes than the largest income datasets. These smaller samples limit the precision of estimates at the state or city level, and may require the pooling of years to obtain precisely estimated changes. As we show, the need for larger samples is significantly offset by the lower variability and higher predictability of consumption, which reduce the standard errors of estimates of changes in consumption relative to those for income. 
The paper proceeds as follows. We first discuss previous studies that examine income and consumption based measures of well-being of the worst off. We then describe the CPS and CE Survey data that we use. Next, we document important differences in recent years for income and consumption based measures of well-being. We follow with an analysis of several dimensions of the relative data quality in the CPS and CE Survey. We then examine whether income or consumption does a better job of predicting measures of well-being at the bottom. Lastly, we offer conclusions and areas for future research.

\section{Previous Research}

A number of studies have documented differences in both levels and trends between consumption and income based measures of well-being for disadvantaged families. Cutler and Katz (1991) show that consumption poverty rose more than income poverty during the 1970s, that both of these poverty measures rose in the early $1980 \mathrm{~s}$, but between 1984 and 1988 income poverty fell while consumption poverty changed little. They also document differences across these measures within demographic groups. Johnson (2004) also finds that consumption poverty increased more than income poverty during the 1970s and then remained steady through 1995 . Using alternative equivalence scales, there is evidence that consumption poverty fell considerably more than income poverty from 1980 through 1995 (Slesnick 2001). Meyer and Sullivan (2003) show that expenditures exceed disposable income for disadvantaged groups such as single mothers, and that the differences are particularly noticeable for those at the very bottom of the distribution. 
In contrast to these papers, Bavier (2007) argues that "there is no huge discrepancy in federal surveys between income and expenditures near the bottom of the distribution." This broad conclusion is based on evidence that changes in consumption poverty are similar to changes in an after-tax disposable income measure. Bavier makes this strong conclusion even though his measures of income and consumption poverty move in opposite directions in recent years and these measures diverge sharply for some demographic groups.

Differences between income and consumption have also been emphasized within the inequality literature. In general, these studies find that the distribution of consumption is substantially more equal than that of income (Cutler and Katz, 1991; Krueger and Perri, 2006; and Johnson, Smeeding, and Torrey, 2005). Krueger and Perri (2006) note that in recent years significant increases in income inequality have not been accompanied by a substantial rise in consumption inequality. Similarly, Johnson, Smeeding, and Torrey (2005) find that consumption inequality increased less than income inequality between 1981 and 2001. They also show that conclusions regarding the relative well-being of different demographic groups are sensitive to whether wellbeing is measured using income or consumption.

Some past work has argued that consumption data should not be used to analyze the well-being of the worst off because patterns for income and consumption poverty are similar and because consumption data are of low quality at the bottom of the distribution (Bavier, 2007). We show that Bavier's conclusions regarding differences between income and consumption are based on a narrow set of results. Moreover, his analysis of 
nonresponse ignores item nonresponse, and his analysis of attrition relies on an inappropriate, non-representative sample.

\section{Data}

\section{The Consumer Expenditure Survey}

Our main consumption data come from the Consumer Expenditure (CE) Interview Survey, which is a rotating panel survey of approximately 7,600 addresses $(5,000$ prior to 1999) where spending is collected for four consecutive quarters. Expenditures are reported for each consumer unit (CU), which consists of individuals related by blood or marriage or who share resources. See the U.S. Department of Labor (various years) for more details on the CE Survey.

Our analyses will examine both expenditures and consumption. To capture total out of pocket spending, we define expenditures as all spending reported in the CE Survey plus principal payments on home mortgages and financed vehicles less the purchase price for financed vehicles. This measure, sometimes called outlays, follows Rogers and Gray (1994). To convert reported expenditures into a consumption measure, we make a number of adjustments. First, to smooth lumpy vehicle expenditures, we convert vehicle spending to a service flow, following the procedure outlined in Meyer and Sullivan (2007). Second, we deduct spending on education, health care and outlays for retirement including pensions and social security which are investments rather than consumption. Third, we measure housing consumption as the reported rental equivalent of the home for homeowners and use reported rent payments for non-homeowners. For CUs living in 
government or subsidized housing, we impute a rental value using geographic information and the characteristics of the living unit (see Meyer and Sullivan, 2007).

\section{The Current Population Survey}

Our main source of income data is the Annual Social and Economic (ASEC) Supplement, formerly called the Annual Demographic File (ADF), to the CPS which includes approximately 100,000 households (60,000 prior to 2002). With these data, we construct two different measures of income: after-tax income plus food stamps and aftertax income plus noncash benefits, which includes food stamps (See the Data Appendix for more details). The first measure captures the resources available for spending, and is therefore the measure we use when comparing income and expenditures. Our second measure, which is more comprehensive, also includes imputed values for housing subsidies and the school lunch program. ${ }^{2}$ We use this measure when comparing income and consumption. The CPS also provides imputed values for other noncash benefits such as health insurance and the net return on home equity. However, there are a number of important limitations with these imputed values. For example, the procedure for imputing Medicare and Medicaid implies that public health insurance has no value for families with very low resources, which surely understates the value of public health insurance for this group. ${ }^{3}$

\footnotetext{
${ }^{2}$ The CE Survey is better designed for imputing values for most noncash benefits. For example, with detailed information on the characteristics of the living unit, the CE Survey is better suited to impute housing subsidies. Also, the reported rental equivalent in the CE Survey better captures the value of owner occupied housing than does the CPS' imputed net return on equity, which is very sensitive to interest rate changes (Meyer and Sullivan, 2006a).

${ }^{3}$ It is important to note that omitting the imputed value for health insurance cannot reconcile differences between consumption and income measures because our consumption measure does not include the value of health insurance.
} 


\section{Panel Study of Income Dynamics}

The Panel Study of Income Dynamics (PSID) is a panel survey that has followed a sample of families, their offspring, and coresidents annually from 1968-1997, and biennially since 1997. The survey provides detailed economic and demographic information for both families and individuals for a sample of about 7,000 families each year. The PSID collects data on a number of different income sources as well as data on food and housing expenditures at the family level.

\section{Recent Changes in Income and Consumption at the Bottom}

Income and consumption reveal different pictures of how the well-being of the worst off has changed. In some cases, income and consumption move in opposite directions in recent years, and often this is the case for the most disadvantaged. Income and consumption do not differ in all cases or in every time period. However, similarities for aggregate measures can hide important differences for subgroups.

Some of the sharpest differences in recent years are for families headed by a single mother. Single mothers are an important group because they were the focus of recent welfare reforms and tax credit expansions, particularly the Earned Income Tax Credit (EITC). In addition, single mother families account for just under 30 percent of the poor and nearly 50 percent of all children in poverty. ${ }^{4}$ Moreover, these families are the primary recipients of many means-tested transfer programs.

In Figure 1 we report the change in mean consumption and mean income for all families headed by a single mother by decile between 1993-1995 (before welfare reform)

\footnotetext{
${ }^{4}$ These figures are based on the authors' calculations using the official definition of poverty and data from the 1994-2003 CPS ADF/ASEC Supplements.
} 
and 1997-2000 (after welfare reform). We report consumption from the CE Survey, after-tax income plus food stamps from the same survey, this same income measure from the CPS, and after-tax income plus noncash benefits. ${ }^{5}$ Two patterns are evident in this figure. First, there is a sharp difference between changes in consumption and changes in income over time. In each decile, consumption rises between 6 and 10 percent. In contrast, income falls sharply, however measured, in the first decile and rises by 5 percentage points more than consumption in deciles 3,4 , and 5 . The differences between the consumption and income changes (for all measures of income) are statistically significant in deciles 1, 3, 4 and 5. These patterns show that the implications of consumption and income in evaluating how material well-being changed after welfare reform are sharply different. Second, there is a striking similarity between changes in CE Survey and CPS income, measured on a comparable basis. The changes never differ by more than a few percentage points, and usually the difference is quite a bit smaller. ${ }^{6}$

These patterns are also evident when we examine changes at each percentile, as shown in Figure 2. Again, we see that the patterns for CPS and CE income are remarkably similar. They show the same negative pattern in the low percentiles and the same peak at the $30^{\text {th }}$ percentile. ${ }^{7}$ We should reiterate that these are from different datasets. On the other hand, changes in consumption differ significantly from changes in comprehensive income.

\footnotetext{
${ }^{5}$ We restrict our CE Survey sample to those designated as "complete income reporters" (see U.S. Department of Labor, various years).

${ }^{6}$ Several studies note that income from the CE Survey is, on average, well below comparable CPS numbers (Cutler and Katz, 1991; Bavier, 2007). A key reason for this is that a large share of CPS income is imputed, whereas, prior to 2004, all missing CE Survey income components are set to zero. Figure 1 shows that even without income imputation in the CE Survey, changes in the percentiles of income line up fairly closely for single mothers. While this is not a broad validation of CE Survey income, it indicates that income data for certain subgroups of the population are reasonably comparable across surveys.

${ }^{7}$ These patterns for income are similar to those in Blank and Schoeni (2003) and Murray and Primus (2005).
} 
We have performed extensive robustness checks that validate the findings in Figures 1 and 2. We have shown that our conclusions about changes in income and consumption during the 1990 s for single mothers are not sensitive to the inclusion of incomplete income reporters in the CE Survey; do not change if we use only the first interview that an address is in the sample for the CE Survey; and are very similar for broadly defined samples of single parents. The results in Figures 1 and 2 are calculated using the NAS recommended equivalence scale, but we verify that these patterns are very similar using the scale implicit in the official poverty thresholds.

The characteristics of the single mother population are changing over time, and these changes may affect both income and consumption. To address this concern, we estimate quantile regressions of the following form:

$\ln \left(\mathrm{Z}_{\mathrm{iq}}\right)=\beta_{1}+\beta_{2} 1_{\{\mathrm{year}=(1997-2000)\}}+\beta_{3} 1_{\{\mathrm{year}=(2001-2003)\}}+\mathrm{X}_{\mathrm{iq}} \beta_{4}+\varepsilon_{\mathrm{iq}}$

where the dependent variable is the log of equivalence scale adjusted consumption or income for family $i$ in quarter $q ; 1_{\{y e a r=(1997-2000)\}}$ and $1_{\{y e a r=(2001-2003)\}}$ are period dummies; $\mathrm{X}_{\mathrm{iq}}$ is a vector of demographic characteristics including a cubic in the age of the head, the number of children less than 18 , the number of girls age $2-15$, the number of boys age 215 , education and race of the head, and region; and $\varepsilon_{\mathrm{iq}}$ is a household-quarter error term. ${ }^{8}$ Columns 1 and 3 of Table 1 , report estimates at various quantiles for $\beta_{2}$ and $\beta_{3}$ when no demographic controls are included $\left(\beta_{4}=0\right)$. As expected, these estimates are in close agreement with those plotted in Figure 2. The estimates for the specifications including demographic controls are reported in Columns 2 and 4. Adding controls has little effect on the trend for consumption, although changes between the 1993-1995 and 2001-2003

\footnotetext{
${ }^{8}$ We calculate bootstrap standard errors, resampling at the household level, rather than at the householdquarter level in order to allow for within household dependence.
} 
periods shift downward somewhat. Estimates for income that account for changes in the characteristics of single mothers no longer exhibit large increases above the bottom quintile. In fact, these income trends mirror those for consumption very closely above the $15^{\text {th }}$ percentile. However, the addition of demographic controls has little effect on changes in income at the bottom. Income still falls between 1993-1995 and 1997-2000 by 19 percent at the $5^{\text {th }}$ percentile and by 8 percent at the $10^{\text {th }}$ percentile and the former change is significant. We also estimated Equation 1 for the sample of single mothers in the CPS (not reported). Consistent with the pattern for CE Survey income, in the CPS we find that much of the significant rise in income above the bottom decile reported in Figures 1 and 2 disappears with the addition of demographic controls. However, as in the CE Survey, we still see a sharp drop in income in the bottom decile.

Table 1 also presents estimates for changes in income and consumption relative to two comparison groups: single women without children and married mothers. These comparison groups provide an indication as to whether the changes we observe are part of a larger pattern of change for other groups due to survey changes or macroeconomic conditions, or other sources. In particular, for a sample including single mothers and a comparison group we estimate specifications similar to Equation 1 that also include interactions of a single mother indicator with each of the three period indicators. Columns 5 through 8 report, for various percentiles, the difference between the coefficient on this interaction with the first period and this interaction with each of the later periods. These results are consistent with the pattern for the absolute changes. At percentiles below the $25^{\text {th }}$, consumption for single mothers rises modestly, but in many cases significantly, relative to both comparison groups. At percentiles above the $25^{\text {th }}$, the 
change in relative consumption is very small. Changes in relative income mirror those for consumption above the $25^{\text {th }}$ percentile. However, we again see noticeable differences at the bottom, where relative income falls for single mothers at the $5^{\text {th }}$ and $10^{\text {th }}$ percentiles, and this drop is significant for the all mothers sample.

If recent macroeconomic changes affect these three groups similarly, then the trends in Columns 5 through 8 suggest that recent changes in welfare and tax policy had a modest positive effect on consumption for single mothers in the bottom quartile, and a very small effect on both consumption and income at higher percentiles. ${ }^{9}$

Figure 3 reports income and consumption measures from the PSID. PSID food consumption exhibits little change during this period. This is similar to the pattern for food consumption in the CE Survey, although for the CE Survey food falls in the bottom half of the distribution. While the PSID does not provide data on total consumption, data are available for housing spending. Together, food and housing account for more than seventy percent of total consumption for single mothers (Meyer and Sullivan, 2006b). ${ }^{10}$ The trend for food and housing in the PSID is fairly similar to the trend for total consumption in the CE Survey shown in Figure 2. These results show that the consumption changes are not an anomaly due to some aspect of the CE Survey. The trends for PSID income show increases over most percentiles. These trends are quite similar to those for the CPS and the CE Survey except in the bottom quintile. Other

\footnotetext{
${ }^{9}$ These three groups of women have similar wages, and this similarity is especially strong for the two groups of single women and when one conditions on educational attainment. Previous research has shown that employment for single women without children responds in a similar way to changes in aggregate unemployment as does employment for single mothers (Meyer and Rosenbaum, 2001).

${ }^{10}$ Housing in the PSID includes rent for renters, a service flow based on the market value of the home for owners, and a reported rental equivalent for non-homeowners that do not pay any rent. Unlike the CE housing measure, it does not include utilities. See Data Appendix for more details.
} 
research indicates that this rise at the bottom in the PSID is due to unusually low levels of reported income in the PSID during the 1993-1995 period. ${ }^{11}$

In a separate study we compare the recent patterns for consumption and income poverty (Meyer and Sullivan, 2006a). Differences in income and consumption trends are less evident for measures of overall poverty. For example, the pattern for consumption based poverty is quite similar to the pattern for poverty based on after-tax income plus noncash benefits for the years from 1984-2000, although these measures move in opposite directions in recent years. Similarities for overall head count poverty mask important differences between income and consumption for key poverty statistics for the entire population. For example, the fraction of people below half the poverty line (or deep poverty) measured using income has risen in the last 20 years, while deep poverty measured using consumption has fallen sharply. Sharp differences are also evident for measures of the poverty gap, or the cumulative amount needed to raise the resources of poor families up to the poverty line.

For children we find that income poverty falls more than consumption poverty. On the other hand, the fall in income poverty for those 65 and older in recent decades is sharply smaller than the decline in consumption poverty (Meyer and Sullivan 2006a, 2007). ${ }^{12}$ It is not surprising that some of the biggest differences between income and consumption would appear for the elderly. For this group, current income is likely to be

\footnotetext{
${ }^{11}$ Gouskova and Schoeni (2002) compare PSID and CPS income between 1970 and 2001 for many points in the distribution. They show that below the 20th percentile PSID income exceeds CPS income for the years prior to 1990. In the early 1990s, however, PSID income at low percentiles falls sharply relative to CPS income, and after 1997 PSID income at these low percentiles grows at a much faster rate than does CPS income.

12 This pattern is consistent with Bavier (2007) who shows that between 1984 and 2004, consumption poverty for those 65 and over fell by more than sixty percent, while income poverty actually increased. Despite these clear differences, Bavier concludes that "comprehensive income and consumption poverty rates are similar for all age groups.”
} 
a poor measure of the resources available for consumption, because the elderly are more likely to be drawing down saving and enjoying the benefits of previous purchases of homes and cars.

The results presented here show that income and consumption measures often tell very different stories about how the well-being of disadvantaged households has changed over the past two decades. These findings are consistent with previous research that has also shown that there are important differences (Cutler and Katz, 1991; Slesnick 1993, 2001; Johnson, 2004). However, these findings contrast sharply with Bavier (2007) who argues that there are not large differences between income and consumption at the bottom.

\section{Data Quality Issues}

In order to assess whether the patterns for income or consumption more accurately capture the well-being of the disadvantaged, we investigate measurement issues for income and consumption at the bottom of the distribution, examining underreporting, survey and item nonresponse, the precision of consumption estimates, and attrition.

\section{Under-reporting of Income and Consumption}

Concerns regarding income under-reporting are well documented (Moore et al., 2000; Coder and Scoon-Rogers, 1996; Roemer, 2000; Meyer and Sullivan 2006b, Meyer, Mok, and Sullivan, 2007). One concern that is particularly relevant for disadvantaged households is the extent of under-reporting of transfer income. We compare weighted micro-data from several national surveys to administrative aggregates for several transfer 
programs and the EITC. These ratios, which are reported in Figure 4, provide a reasonable estimate of the fraction of dollars received that are reported in the CPS. ${ }^{13}$ This analysis indicates that the reporting rate for most transfer programs is quite low, and for some programs, such as AFDC/TANF and food stamps, the reporting rate has been falling sharply over time. In the most recent year the share of TANF dollars reported in the CPS was 54 percent, and the fraction of food stamps dollars reported was 57 percent. The corresponding shares for unemployment insurance, Supplemental Security Income (SSI), workers' compensation, and the EITC were 63, 78, 48 and 74 percent. Meyer, Mok, and Sullivan (2007) also report sharp under-reporting of transfers in the Panel Study of Income Dynamics (PSID) and the Survey of Income and Program Participation (SIPP).

The potential effect of changes in under-reporting on recent income trends is unclear. On the one hand, sharp increases in under-reporting of transfer income could lead to a significant downward bias in changes in measured income. On the other hand, for some of these programs, such as AFDC/TANF, true receipt also declined significantly in recent years. Consequently, the number of dollars not reported rose slowly between 1993 and 2000. Thus, at least for AFDC/TANF, it is possible that declining true receipt could reverse much of the effect of a lower reporting rate. In addition, the shift from welfare to work could bias income trends upward as labor market earnings replace welfare income, because this change represents a shift from a source that is significantly under-reported to one that is typically well-reported (Roemer, 2000). Nevertheless, in

\footnotetext{
${ }^{13}$ False positive reporting by nonrecipients would lead the ratio to overstate reporting by true recipients. Some differences in the sample universe, such as the exclusion of those living abroad and in institutions, leads to some understatement of reporting.
} 
Meyer and Sullivan (2006b) we conclude that under-reporting of transfers can explain more than half of the decline in income in the bottom decile that we report in Figure 1.

Strong evidence that income is under-reported at the bottom of the distribution is that expenditures exceed income. In Table 2 we report percentiles of the income distribution from the CPS, and percentiles of the income and expenditure distributions from the CE Survey. ${ }^{14}$ We examine expenditures rather than consumption, because the former should equal after-tax income in the absence of saving or dissaving. For all families (Panel A), the $5^{\text {th }}$ percentile of the CE Survey expenditures distribution is 44 percent higher than the $5^{\text {th }}$ percentile of the CPS income distribution, which is close to the mid point of the distribution for the poor. A difference is also evident, but much less extreme, at the $10^{\text {th }}$ percentile where CE Survey expenditures exceed CPS income by 8 percent. Average expenditures for families below the $5^{\text {th }}$ percentile of expenditures are more than three times greater than the average income for all families below the $5^{\text {th }}$ percentile of income (compare Rows 2 and 7).

We should note that the CE Survey expenditure numbers that we report should really be scaled up in comparison to the CPS numbers because they are four times a quarterly number, whereas income is annual. The quarterly numbers will be more variable compared to annual numbers leading low percentiles to be lower than they would be with annual expenditure numbers. By examining observations where we have both four quarterly numbers and annual numbers, we find that the $5^{\text {th }}$ percentile should be

\footnotetext{
${ }^{14}$ We use after-tax income plus food stamps rather than a more comprehensive income measure, because the former is more comparable to expenditures. See the data section for more details.
} 
adjusted upward by 11 percent and the $10^{\text {th }}$ percentile by 10 percent. ${ }^{15}$ Thus, the true discrepancies between income and consumption at the bottom are even larger than those reported in Table 2.

By looking at income and expenditures within the CE Survey, we can compare these measures for the same families in the bottom of the income distribution (compare Rows 4 and 8) or the bottom of the expenditure distribution (compare Rows 5 and 7). Expenditures exceed income by a factor of 7.12 in the bottom five percent of the income distribution, while income exceeds expenditures by only a factor of 1.55 in the bottom five percent of the expenditure distribution. Bavier (2007) is critical of such comparisons, because they rely on CE Survey income, which he claims is inferior. However, as evident from comparing Rows 1 and 3 , the $5^{\text {th }}$ and $10^{\text {th }}$ percentiles of CE Survey income are fairly similar to the corresponding percentiles of the CPS income distribution. The $5^{\text {th }}$ percentile differs by 3 percent and the $10^{\text {th }}$ by 9 percent. ${ }^{16}$ CPS income exceeds CE Survey income at higher percentiles which is not surprising given that the CPS imputes missing values of income components while the CE Survey sets them to zero.

Similarities between CE Survey income and CPS income are even stronger for the sample of all single mothers (Panel B). For this group, the percentiles of CPS income exceed those of CE Survey income by only a few percent through at least the median. The $5^{\text {th }}$ percentile of CE Survey income even exceeds that from the CPS. Moreover, we

\footnotetext{
${ }^{15}$ These adjustment factors are based on the results in Appendix Table A.1 which compares the distribution of expenditures based on annualized quarterly expenditures to that based on annual expenditures using those observations where we have both four quarterly numbers and annual numbers.

${ }^{16}$ We do not interpret the similarity between CE Survey income and CPS income as indicating that CE income is of high quality. Rather, these similarities suggest they we should be concerned about the quality of income at the bottom in both surveys.
} 
showed in Figures 1 and 2 that changes in income for single mothers are very similar across the two surveys. For this group, expenditures exceed income by a factor of 3.8 for those in the bottom income decile (Rows 12 and 16) and by a factor of 2.4 for those in the bottom income quintile. Again, there is evidence that CE Survey expenditures exceed CPS income (Rows 9 and 14). Expenditures are nearly 50 percent greater than CPS income when comparing the $5^{\text {th }}$ percentiles, and spending exceeds income by more than 25 percent at the $20^{\text {th }}$ percentile.

In addition to the reasons discussed above, we have focused on single mothers in some of our previous work because it allows us to examine a disadvantaged group without conditioning on low income or low consumption. For example, an alternative interpretation of the finding that expenditure percentiles exceed income percentiles is that households are able to draw down assets (that saving and dissaving explain the difference). This pattern would be consistent with the permanent income hypothesis. Based on the very low asset holdings of single mothers (Meyer and Sullivan, 2003, 2006b), we do not think the permanent income hypothesis is the key explanation for this group. Thus, we conclude that for this large group of the poor, the explanation for the difference is likely to be under-reporting.

Another potential explanation for the differences between income and consumption shown in Table 2 is that expenditures are over-reported. However, there is little evidence of over-reporting of expenditures. Rather, past work (Gieseman, 1987; Slesnick, 1992; Garner et al., 2006; Attanasio et al., 2006; Hassett et al., 2007) has emphasized concerns about under-reporting of expenditures in the CE Survey. This literature has compared CE Survey aggregates with Personal Consumption Expenditure 
(PCE) data from the National Income and Product Accounts (NIPA), noting that the $\mathrm{CE} / \mathrm{PCE}$ ratio is about 0.62 in recent years. Some of this evidence is easily misinterpreted and is less applicable to the current analyses than it may seem for several reasons. First, many published comparisons are based on the integrated data that combine CE Diary and CE Interview data rather than the Interview data used exclusively here. Second, the poor consume a different bundle of goods than non-poor families, so that aggregate analyses do not reflect the composition of consumption for the poor. Third, the PCE numbers cover a different population, are defined differently from the CE, and are the product of a great deal of estimation and imputation that is subject to error. One should not expect expenditures weighted by the population to match PCE aggregates. The Bureau of Economic Analysis reported that in 1992 more than half of the difference between PCE and CE Survey consumer spending was due to coverage and definitional differences (summarized in GAO, 1996).

In Table 3 we report comparisons of CE Interview Survey values weighted by population to corresponding categories of PCE data, focusing on categories of expenditures that are a large share of spending by the poor: food and rent. These comparisons show that reporting rates for components of consumption that are particularly important to poor families are higher and steadier than the rates for expenditures as a whole. Between 1984 and 2002, the CE/PCE ratio for food at home was, on average, about 0.80 , and for rent plus utilities the ratio was about 0.95 . The ratio for rent plus utilities remained virtually unchanged between these two years. 


\section{Survey and Item Nonresponse}

Measures of nonresponse are often used to evaluate the quality of data from a survey (Atrostic et al., 2001; Atrostic and Kalenkoski, 2002). Nonresponse can bias statistical analyses if those who do not respond are different from those who do. Nonresponse is often divided into survey nonresponse and item nonresponse. Survey nonresponse includes cases where no information is obtained for a sample household for reasons such as inability to contact any person in the household or a refusal to respond by those contacted. Item nonresponse occurs when a respondent provides some information, but does not provide valid information on a given item. In the case of item nonresponse, the CPS ADF/ASEC imputes values for income based on the individual's or household's characteristics. Similarly, the CE Survey provides imputed values for expenditures.

In Table 4 we report the survey nonresponse rate and the fraction of dollars imputed for income in the CPS and for expenditures in the CE Interview Survey from 1993 through $2003 .{ }^{17}$ Survey nonresponse is similar in the early 1990 s, but the survey nonresponse rate for the CE Survey has risen to about 5 percentage points higher in the most recent years. The evidence in Columns 3-6 indicates that imputation is much more prevalent in the CPS. We calculate imputation rates as the fraction of income or expenditures that are imputed. For pre-tax money income, CPS imputation rates start out 5 percentage points higher than CE Survey rates in 1993, and this difference has increased in recent years. We also examine after-tax income plus Food Stamps, which is a better measure of the resources available to the family and is more comparable to

\footnotetext{
${ }^{17}$ We have adopted the convention that when a person responds to the monthly CPS survey but not to the ADF/ASEC supplement (the source of annual income data) we treat that situation as survey nonresponse and do not include it in the imputation rates (even though all income data are imputed in this case). This convention insures that we do not double count such cases as both survey nonresponse and imputation.
} 
expenditures. ${ }^{18}$ We consider two ways of handling the tax imputations even though, in fact, all taxes are imputed in the CPS. First, we consider taxes to be imputed if more than half of pre-tax income is imputed. Second, we consider all taxes to be imputed. Under the first assumption (Column 4), imputation rates for the CPS are between 15 and 27 percentage points higher than the CE Survey rates. Under the second assumption, when all taxes are considered to be imputed (Column 5), imputation rates in the CPS range from 34 to 47 percentage points higher than the CE Survey. While it is unclear which is the preferred measure to use, it should be evident that imputation rates are much higher in the CPS. A total measure of nonresponse can be calculated as: Total nonresponse = survey nonresponse $+(1$-survey nonresponse)*imputation rate. Such a measure shows much higher total nonresponse in the CPS than the CE Survey. ${ }^{19}$ A complete discussion of nonresponse would analyze the nonrandomness of nonresponse and the accuracy of imputations, but such analyses are beyond the scope of this paper.

Our results for nonresponse are in sharp contrast to a recent study that argues that nonresponse is more problematic in the CE Survey than in the CPS (Bavier, 2007). This argument, however, ignores item nonresponse, which we have shown above to be greater for CPS income than for CE Survey expenditures. In addition, the discussion of survey nonresponse in Bavier (2007) is inaccurate and misleading. ${ }^{20}$

\footnotetext{
${ }^{18}$ Alternatively, one could compare consumption to a more comprehensive measure of income, both of which include additional imputed components. Typically, these additional components are added to both income and consumption, such as the value of owner occupied housing or the value of housing subsidies. ${ }^{19}$ This measure of total nonresponse treats survey and item nonresponse equally. A more sophisticated measure would reflect the degree of nonrandomness in the two sources of nonresponse and the imputation error in the case of item nonresponse.

${ }^{20}$ First, in choosing survey nonresponse rates for the CPS to compare to the CE, Bavier reports the rates for the monthly CPS (which is a ten minute long survey that does not include the income questions) rather than the rates for the ASEC (a lengthy survey which includes the income questions). Later, Bavier reports a survey nonresponse rate for the CE Survey of 27.5 percent and a "comparable" rate for the CPS of 14.4 percent. As shown in Column 1 of Table 3, the latter rate is at the bottom of the range of survey
} 


\section{The Precision of Poverty Measures and the Lower Variability of Consumption}

One advantage of the CPS ADF/ASEC relative to the CE Survey as currently designed is that the former survey has a much larger sample, which provides more precise estimates of certain statistics. The CPS ASEC currently includes approximately 100,000 households, while the CE Interview Survey includes approximately 7,600 households. A given household in the CE Survey provides up to four consumption observations over the year which narrows the gap in sample size. This smaller sample size suggests that current survey data for examining consumption at the state or local level, and changes from one year to the next may be fairly imprecise. For statistics such as the head count poverty rate where precision is roughly proportional to the square root of the sample size, this smaller sample size is especially important. For other statistics, the lower variability of consumption may outweigh the small sample size.

Past work has argued that smaller sample sizes in the CE Survey necessarily imply that consumption is less precise (Citro and Michael 1995; Bavier 2007). These arguments are overstated, because they omit the fact that the variance of income is much larger than that of consumption and income is less predictable, which negatively affects the precision of income based statistics. The lower variability of consumption means that fewer consumption observations than income observations are needed to obtain a given level of precision or significance in some common types of analyses.

nonresponse rates for the CPS between 1993 and 2003. More importantly, the nonresponse rate Bavier reports for the CE Survey is incorrect. It is not the fraction of eligible interviews that are not completed. Rather, this statistic counts as noninterviews those cases where an interview was not intended because the residence was vacant, under construction, demolished, etc. (Reyes-Morales, 2005, Tables 1 and 2). These ineligibles account for nearly half of all noninterviews used to compute the statistic that Bavier reports. The true rate is much closer to the CPS rate. Comparing the average survey nonresponse rate in Table 3 across surveys we find that survey nonresponse for the CE Survey exceeds that for the CPS ADF/ASEC by 4.4 percentage points — or less than half the difference reported in Bavier (2007). 
To demonstrate this point, we estimated a typical regression that is used to determine the change over time for one group relative to a comparison group. For example, we regress income or consumption on time period indicators interacted with demographic group indicators while controlling for other demographic characteristics. Results from these regressions, reported in Table 5, indicate that consumption can provide more precise estimates. The mean ratio of the income based standard errors to the consumption based standard errors, depending on the dataset and comparison group used, ranges from 1.66 to $2.07 .{ }^{21}$ The lower consumption based standard errors were due to a sharply lower variance of consumption and a much higher predictability of consumption (higher $\mathrm{R}^{2}$ ) as can be seen in the last two rows of each panel of Table 5 . Since the standard error is proportional to the inverse of the square root of the sample size, these ratios indicate that each consumption observation is worth about 3 or 4 income observations in terms of precision and the ability to test hypotheses. Thus, even a relatively small consumption dataset may be as useful as a larger income dataset for certain common analyses. Nevertheless, the sample size of the CE Survey would need to be increased in order to obtain estimates of consumption based poverty rates for small geographic areas or for very narrow demographic groups.

\section{Attrition and Other Robustness Issues}

We verify that the consumption patterns for disadvantaged families from the $\mathrm{CE}$ Survey, such as those presented in Section IV or Table 2, are not biased due to nonrandom attrition in the CE Survey or sample restrictions such as the exclusion of incomplete income reporters. We show in Table 6 that differences in spending between

\footnotetext{
${ }^{21}$ The number of observations with nonmissing income data is slightly smaller than those with consumption data, but this difference accounts for only a tiny share of the difference in these comparisons. Significantly larger standard errors for income are also evident in the results presented in Table 1.
} 
complete income reporters and incomplete income reporters is not large enough to change substantially the distribution of consumption for the bottom half of the distribution (compare Rows 1 and 2 for each sample). For all families, the percentiles of consumption for the samples that include only complete income reporters (our base sample) never differ by more than 2 percent from the percentiles for the full sample. For specific disadvantaged groups, the differences are typically less than 2.5 percent. $^{22}$ None of the analyses of consumption or expenditures that we present in this paper are sensitive to the inclusion or exclusion of incomplete income reporters. ${ }^{23}$

To examine how attrition might bias our analyses of consumption, Table 6 also reports various percentiles for a sample that only includes data from second quarter interviews. Second quarter interviews are the first for which the full survey is administered for each sampling unit (the first interview just gathers baseline information). The CE Survey is a sample of addresses, not consumer units (CUs). Those who move away from their sample address between interviews are dropped from the survey, while those moving into a sample address are included in the survey after being screened for eligibility (U.S. Department of Labor, various years). These first full interviews for housing units (second quarter interviews) are close to a random sample of housing units as is intended in the survey. As is evident by comparing Rows 2 and 3 for all families, and within each demographic group, the bottom part of the distribution for the second

\footnotetext{
${ }^{22}$ A similar analysis for expenditures indicates that the differences for these percentiles are never greater than five percent.

${ }^{23}$ This contradicts claims by Bavier (2007) that "Expenditures of CE 'complete income reporters' are not representative of all consumer units." Bavier argues that average expenditures for complete income reporters exceed those of other consumer units. However, most of the difference is due to differences in spending on insurance and pensions, which is typically excluded from measures of consumption. Moreover this difference arises because income data are used to impute this insurance component. Whether income data are complete matters crucially for this imputation. When insurance is excluded, spending for complete income reporters is only slightly higher than spending for incomplete income reporters.
} 
quarter interview sample is remarkably similar to that of the full sample. This suggests that including data from interviews beyond the second quarter does not bias analyses of consumption, even within demographic groups.

Bavier (2007) examines attrition by restricting his sample to the first reported interview for each consumer unit (not housing unit). For this sample, he compares consumption across CUs that differ in the number of quarters of reported expenditures. Thus, he is comparing samples that have different shares of CUs that have just moved residences. For example, the four quarter sample will be CUs who never move during the sample period, while movers will be over-represented in the one quarter sample. These samples are all non-representative and should differ from each other even when attrition is random. Comparisons of consumption across these non-representative samples lead Bavier to conclude mistakenly that "sample loss is negatively related to economic status." The fourth row of each panel in Table 6 reports consumption percentiles for Bavier's unconventional sample of first reported interview for each CU. It is not surprising that expenditures for this sample that over-represents movers are lower than for other samples.

\section{Consumption and Income as Predictors of Well-Being}

The relative quality of income and consumption data at the bottom can be investigated by determining whether low consumption or low income is more closely associated with other bad outcomes (Meyer and Sullivan, 2003). We examine whether low values of income or consumption are more closely related to poor health, disability, and worse values of measures of material well-being such as the size of the residence, number of cars, whether the family took a vacation, and whether the family has access to 
certain appliances within the dwelling unit. Table 7 examines how outcomes differ for families in the bottom five percent of the consumption and income distributions compared to all other families using CE Survey and PSID data. Column 1 reports the mean value of each outcome for those in the bottom five percent of the income distribution, while Column 2 reports the mean for those in the top ninety-five percent of the income distribution. If higher values of the outcome are better, as we expect given the way all outcomes are defined in the table, the difference in Column 3 should be negative if those at the bottom of the income distribution fare worse than others. Similarly, in Columns 4 through 6 we report the same statistics for groups defined by their place in the consumption distribution. Column 7 reports the key difference-indifferences summary measure, which should be negative if low consumption is a better indicator of bad outcomes than is low income.

The results in this table indicate that low consumption is usually a better indicator of hardship than income. For the CE Survey, the negative values in Columns 3 and 6 indicate that in all cases, those in the bottom 5 percent of income or consumption experience worse material conditions than those above the bottom 5 percent. Column 7 indicates that in all cases low consumption is a clearer indicator of worse outcomes than low income. Moreover, in all but three of these cases, the statistic in Column 7 is significantly different from zero.

The PSID results are less strong, but still favor consumption. Seven of the ten statistics in Column 7 are negative, which favors consumption, and four of these are significant. Surprisingly, low income seems to be significantly more closely associated with low automobile ownership than is low consumption in the PSID. We should note 
that consumption is handicapped in the PSID, where we believe the income data are of higher quality than the consumption data, while the reverse is true in the CE Survey. Also, the results are likely biased towards favoring income in the PSID due to the longer reference period for income (the previous calendar year) than food expenditures (a typical week).

We also examine the relationship between low consumption, low income, and the same outcomes listed in Table 7 for a number of disadvantaged groups such as all single mother headed families, families with a head age 65 and over, and families with a disabled head. We summarize the results of these analyses in Table 8 , by reporting the number favoring income (the difference-in-differences statistic is positive) and the number favoring consumption (the difference-in-differences statistic is negative). The evidence from the CE Survey again strongly favors consumption, and in most cases this evidence is statistically significant. For the PSID, we also see more of these outcomes favoring consumption than income within each of these disadvantaged groups. However, due to small sample sizes for these groups, the results from the PSID are not very precise.

Charles et al. (2006) perform a similar analysis to ours for a sample of those 53 and over using the 2001 Consumption and Activities Mail Survey (CAMS) of the Health and Retirement Study (HRS). For the full sample, they find that income is more strongly associated with measures of well-being than their measure of consumption. However, for the bottom decile (roughly those who are poor) the evidence strongly favors consumption for physical health and wealth measures. The evidence is mixed for housing and neighborhood measures, and strongly favors income for measures of mental health in the past week and food hardship. It is somewhat surprising to find even modest support for 
consumption given that the HRS focuses on income while the consumption data come from a supplement mailed to a subsample of HRS households.

Using data from the Survey of Income and Program Participation (SIPP), Bavier (2007) indicates that income is more strongly correlated with material hardship than is expenditures. However, his measure of expenditures from the SIPP is inappropriate for this analysis because it includes components that may indicate worse well-being, such as out of pocket medical expenses, child care, and work expenses, and because consumption of owner-occupied housing is measured using mortgage payments — an approach most researchers examining consumption have rejected (Cutler and Katz, 1991; Slesnick, 1993; Meyer and Sullivan, 2003, 2004). Using an alternative consumption measure that is as good as one can do with the limited information in the SIPP, we find that its correlation with the various hardship measures is the same or higher than that of income. ${ }^{24}$ This result is especially striking because the SIPP provides probably the best measure of income available in any standard household dataset (Citro and Michael, 1995; Meyer, Mok and Sullivan, 2007), while the consumption data are based on a little used supplement that provides only about half of total spending and misses key components such as food consumption.

\section{Discussion and Conclusions}

This paper shows that recent changes in income and consumption differ sharply for some disadvantaged groups and measures of poverty. For example, following welfare reform, reported income for the bottom decile of single mothers fell as some past authors

\footnotetext{
${ }^{24}$ Specifically, we sum utilities, rent, and the flow values of homes and vehicles, which are calculated based on the reported values of these durables.
} 
have emphasized, but we show reported consumption rose. In many cases where income and consumption patterns diverge, consumption measures show greater improvements than income measures. However, the reverse is true for child poverty. This paper also addresses standard criticisms of the quality of consumption data. These criticisms usually focus on sample size, measurement error, and the declining share of NIPA consumption captured by the CE Survey. We present substantial evidence that consumption data are measured better than income data at the bottom of the distribution. This empirical evidence supports conceptual arguments that generally favor consumption. The bottom deciles of expenditures exceed those for income suggesting under-reporting of income. There is a high and rising under-reporting rate for government transfers, a source of income that is particularly important at the bottom. In addition, the nonresponse and imputation rates are similar or higher in our source of official income data than in our main source of consumption data. Finally, low consumption for the worst off among the disadvantaged seems to be more closely associated with other bad outcomes than is low income. The results favoring consumption are strongest when examining the bottom 5 or 10 percent of the distribution; the evidence is more mixed higher up in the distribution, particularly for those 65 and over. The evidence favors consumption, or is mixed, in surveys such as the PSID, SIPP, and HRS-CAMS. Given that these surveys focus on income or have incomplete measures of consumption, this evidence is even a stronger endorsement of consumption.

The findings in this paper are in sharp contrast to Bavier (2007). We show that these differences arise because Bavier draws broad conclusions based on a narrow set of results and employs inappropriate procedures for studying data quality. For example, 
Bavier (2007) claims that "there is no huge discrepancy in federal surveys between income and expenditures near the bottom of the distribution." This conclusion is based on results for overall poverty only, ignoring large differences between income and consumption for key demographic groups, as well as divergent trends in poverty gaps and deep poverty, and other differences. Bavier (2007) also suggests that income data are of higher quality than consumption data. However, we show that Bavier's conclusions regarding nonresponse are flawed because he reports non-comparable numbers for survey nonresponse and he completely ignores item nonresponse. In addition, his analysis of sample attrition is based on an unconventional, non-representative sample. Finally, we show that Bavier's analysis of the correlation between hardship measures and income or consumption depends on an expenditure measure that heavily weights items such as child care, work expenses, and out of pocket medical expenses that are conventionally left out of consumption. Using the same dataset, we find that a more conventional and appropriate consumption measure reverses his result.

Although the evidence presented here indicates that greater attention should be given to consumption when studying the well-being of disadvantaged households and the effects of anti-poverty programs, there are some important limitations of consumption data. For example, income data are easier to collect for determining individual program eligibility. Also, the sample sizes in the best consumption datasets currently available are too small to measure precisely poverty for small geographic areas or to measure year to year changes.

Differences between income and consumption at the bottom remain a puzzle. The relative importance of unreported income and saving or dissaving is not clear, especially 
for groups besides single mothers. Further research is needed to examine the reasons for these differences. In addition, more research is needed on how to obtain a reasonable consumption measure from a small set of questions, as examined in Browning et al., 2003, and on how to synthesize questions about expenditures and durable holdings into consumption measures. 


\section{References}

Atrostic, B.K. and Kalenkoski, C., 2002, "Item Response Rates: One Indicator of How Well We Measure Income.” In proceedings of the annual meetings of the American Statistical Association (ASA), August 11-15.

Attanasio, Orazio P., Erich Battistin, and Andrew Leicester. 2006. "From Micro to Macro, from Poor to Rich: Consumption and Income in the UK and the US,” working paper, University College London.

Bavier, R. (2007), “Income and Expenditure Data in Poverty Measurement.” Journal of Policy Analysis and Management, forthcoming.

Blank, Rebecca and Robert Schoeni, "Changes in the Distribution of Child Well-Being Over the 1990s, American Economic Review: Papers and Proceedings, 2003, 93(2): 304-308.

Browning, M., Crossley, T. F. and Weber, G., 2003. "Asking Consumption Questions in General Purpose Surveys." Economic Journal, 113 (November), F540-F567.

Burtless, G. and Smeeding, T. 2001. "The Level, Trend, and Composition of Poverty." In S. Danziger and R. Haveman, eds., Understanding Poverty, Cambridge, MA: Harvard University Press, 27-68.

Charles, K. K., Danziger, S., Pounder, L., and Schoeni, R.F. 2006. “Consumption, Income, and Well-Being Among the Mature Population,” National Poverty Center working paper, April 2006.

Citro, C. F. and Michael, R. T. (1995). Measuring Poverty: A New Approach, eds. Washington, D.C.: National Academy Press.

Coder, J. and Scoon-Rogers, L. 1996. “Evaluating the Quality of Income Data Collected in the Annual Supplement to the March Current Population Survey and the Survey of Income and Program Participation.” Housing and Household Economic Statistics Division. Washington D.C.: U.S. Census Bureau.

Cutler, D. M. and Katz, L.F. 1991. "Macroeconomic Performance and the Disadvantaged.” Brookings Papers on Economic Activity 2: 1-74.

Edin, K. and Lein, L. 1997. Making Ends Meet: How Single Mothers Survive Welfare and Low-Wage Work. New York: Russell Sage Foundation.

General Accounting Office. 1996. “Alternative Poverty Measures,” GAO/GGD-96183R. Washington, DC: Government Printing Office.

Gieseman, R. 1987. “The Consumer Expenditure Survey: quality control by comparative analysis,” Monthly Labor Review, 8-14.

Gouskova, Elena, and Robert F. Schoeni. 2002. "Comparing Estimates of Family Income in the Panel Study of Income Dynamics and March Current Population Survey, 1968-1999.” Working paper, Institute for Social Research, University of Michigan.

Gruber, J.. (1997). The Consumption Smoothing Benefits of Unemployment Insurance. American Economic Review, 87(1), 192-205.

Jencks, C., S. E. Mayer, and J. Swingle. 2004. "Who Has Benefitted from Economic Growth in the United States Since 1969? The Case of Children.” in E. N. Wolff, ed. What Has Happened to the Quality of Live in the Advanced Industrial Nations? Cheltenham, UK: Edward Elgar. 
Joint Economic Committee Democrats (JEC). 2004. "Reduction in Poverty Significantly Greater in the 1990s than Official Estimates Suggest,” Policy Brief, August.

Johnson, D. S., Smeeding, T. M., and Torrey, B.B. 2005. Economic Inequality Through the Prisms of Income and Consumption. Monthly Labor Review. April, 11-24.

Krueger, D. and Perri, F. 2006. "Does Income Inequality lead to Consumption Inequality? Evidence and Theory" Review of Economic Studies 73, pp. 163-193.

Marquis, K. H. and Moore, J. C. 1990. "Measurement Errors in SIPP Program Reports." In Proceedings of the 1990 Annual Research Conference, 721-745. Washington, DC.: U.S. Bureau of the Census.

Meyer, Bruce D. and Dan T. Rosenbaum. 2001. "Welfare, the Earned Income Tax Credit, and the Labor Supply of Single Mothers," Quarterly Journal of Economics, CXVI, 1063-1114.

Meyer, B. D., Mok, W. K. C. and Sullivan, J. X. 2007. "The Under-Reporting of Transfers in household Surveys: Comparisons to Administrative Aggregates" working paper, April.

Meyer, B. D., Sullivan, J. X.. 2007. "Consumption and Income Poverty for those 65 and Over," working paper, July.

----. 2006a. "Three Decades of Consumption and Income Poverty,” working paper, September.

----. 2006b. "Consumption, Income, and Material Well-Being After Welfare Reform,” NBER Working Paper 11976, January.

----. 2004. "The Effects of Welfare and Tax Reform: The Material Well-Being of Single Mothers in the 1980s and 1990s," Journal of Public Economics, 88, July, 13871420.

----. 2003. "Measuring the Well-Being of the Poor Using Income and Consumption." Journal of Human Resources, 38:S, 1180-1220.

Moore, J. C., Stinson, L.L. and Welniak, E. J. Jr. 2000. "Income Measurement Error in Surveys: A Review.” Journal of Official Statistics, 14:4, 331-361.

Murray, Kasia O’Neill and Wendell E. Primus 2005. "Recent Data Trends Show Welfare Reform to Be a Mixed Success: Significant Policy Changes Should Accompany Reauthorization” Review of Policy Research, 22:3, 301-324.

Rogers, J. M. and Gray, M. B. 1994. "CE Data: Quintiles of Income Versus Quintiles of Outlays.” Monthly Labor Review 117(12): 32-37.

Roemer, M. I. 2000. "Assessing the Quality of the March Current Population Survey and the Survey of Income and Program Participation Income Estimates, 19901996.” Staff Papers on Income, Housing and Household Economic Statistics Division. Washington D.C.: U.S. Census Bureau.

Sawhill, I. (1988), “Poverty in the U.S.: Why Is It So Persistent?” Journal of Economic Literature, 26, September, 1073-1119.

Slesnick, D. T. 1993. “Gaining Ground: Poverty in the Postwar United States.” Journal of Political Economy 101(1): 1-38.

-----. 2001. Consumption and Social Welfare. Cambridge: Cambridge University Press.

U.S. Census Bureau, Statistical Abstract of the United States, 2006 Edition. USGPO: Washington, DC.

----. various years. "Current Population Survey, 2004 ASEC Technical Documentation." Washington, DC. 
U.S. Department of Labor (various years), "Consumer Expenditure Interview Survey Public Use Microdata Documentation,” U.S. Department of Labor, Bureau of Labor Statistics, Division of Consumer Expenditure Surveys. 


\section{DATA APPENDIX}

After-Tax Money Income Plus Food Stamps (CE Survey, CPS, and PSID) adds to money income the value of tax credits such as the EITC, and subtracts state and federal income taxes and payroll taxes, and includes capital gains and losses, and adds the face value of Food Stamps.

After-Tax Income Plus Noncash Benefits (CPS) adds to After-tax Money Income Plus Food Stamps the imputed cash value of housing subsidies, and school lunch programs. Expenditures (CE Survey) start with the BLS measure of total expenditures. We add principal payments on home mortgages and financed vehicles, and subtract the purchase price for financed vehicles. This measure, sometimes called outlays, follows Rogers and Gray (1994). Expenditures are reported for three-month periods. We scale these quarterly expenditures to an annual level.

Consumption (CE Survey) subtracts from the BLS measure of total expenditures spending on health care, education, pension plans, and cash contributions. In addition, housing and vehicle expenditures are converted to service flows. The rental equivalent for owned dwellings is used instead of spending on mortgage interest, property taxes, and spending on maintenance, repairs, and insurance. For those in public or subsidized housing, we impute a rental value. We subtract spending on vehicle purchases and add a vehicle service flow. See Meyer and Sullivan (2006a) for more details.

Food Consumption (PSID) includes expenditures on food at home and away from home and dollars of food stamps received.

Housing (PSID) does not include utilities or other housing costs because they are not available throughout our sample period in the PSID. It includes rent for renters and the 
reported rental equivalent for those who neither rent nor own. For homeowners, we calculate a service flow of housing consumption based on the value of the home. This flow is calculated as a constant fraction (r) of the reported property value. This is the service flow for a durable with an after-tax interest rate $r$ and with no depreciation. The results reported in Figure 3 are for $r=0.07$, but we verify that the results do not change when we use values of $r$ between 0.05 and 0.1 . In addition, within the CE Survey this flow matched up fairly well with reported rental equivalent of the home.

Equivalence Scales are used to adjust resource measures for differences in family size. In most cases we use the equivalence scale recommended by the National Academy of Sciences panel (Citro and Michael 1995): (Adults $+0.7^{*}$ Children) $)^{0.7}$. As a robustness check, we verify that the trends are similar using the equivalence scale implicit in the official poverty definition. 


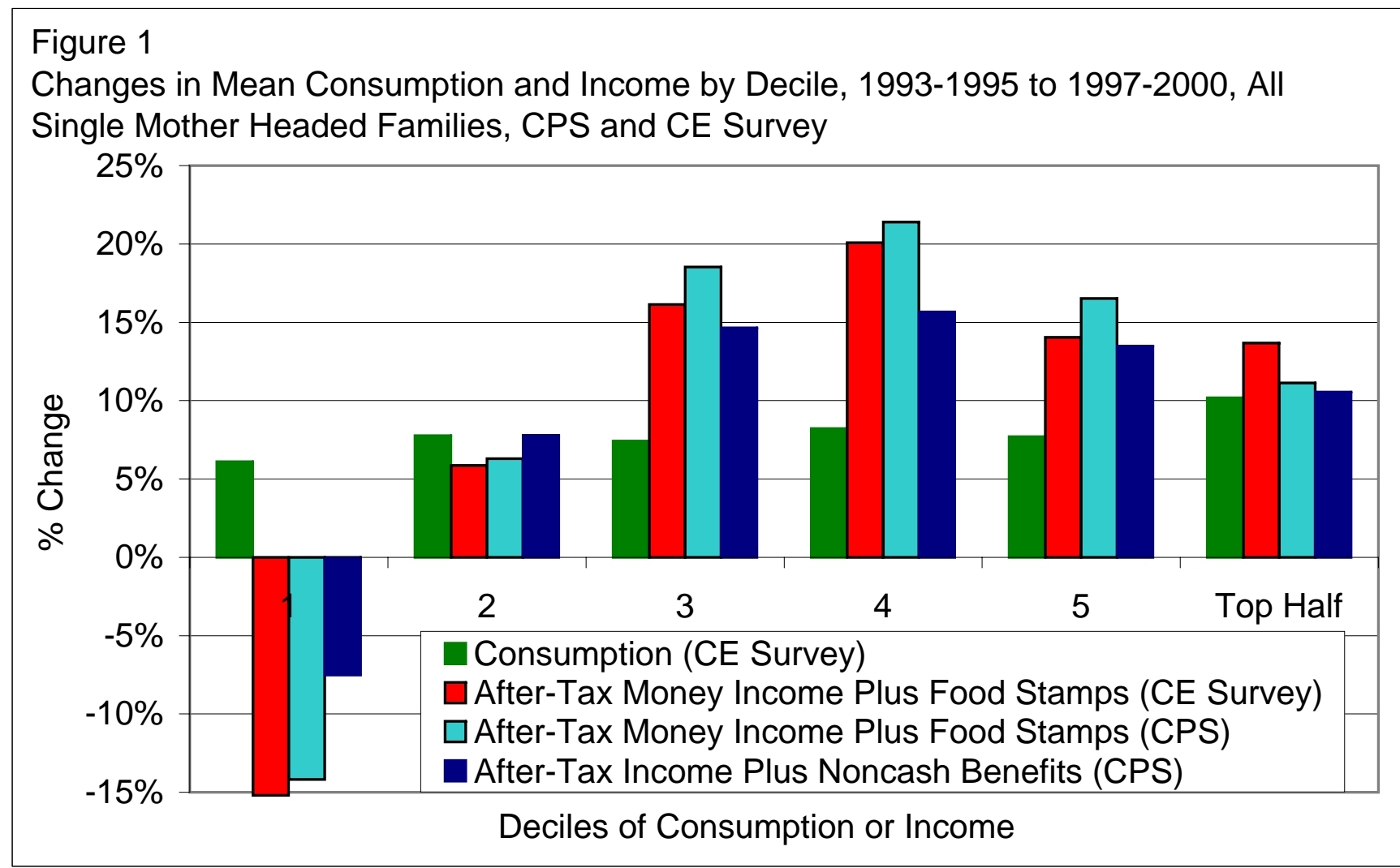

Notes: The samples include all unmarried female headed families/consumer units living with at least one child under 18. The changes are in real terms and outcomes are adjusted for differences in family size using the NAS recommended equivalence scale. Each outcome is sorted by itself. See the Data Appendix for definitions of income and consumption. The CE Survey sample excludes those designated as incomplete income reporters. See text for more details. 


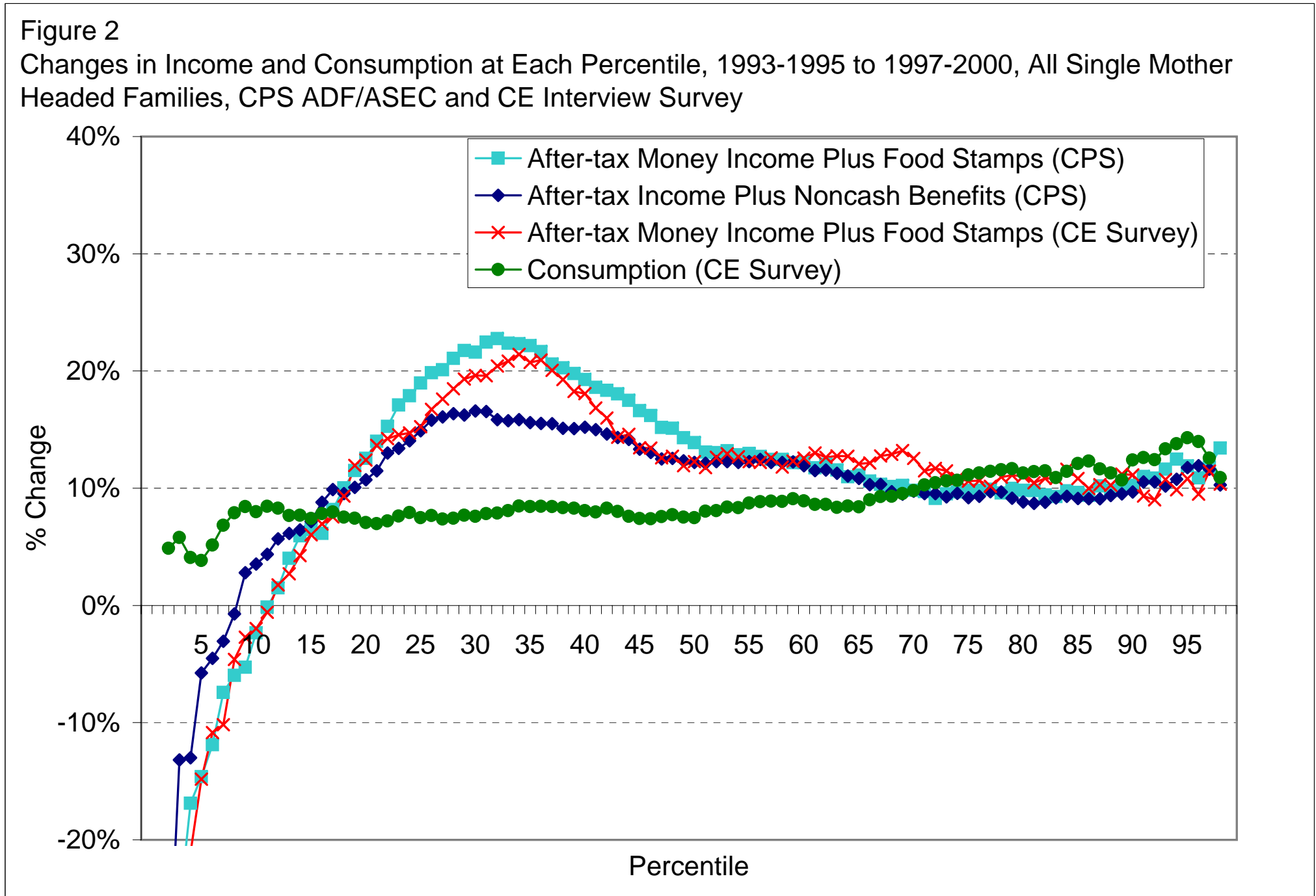

Notes: See notes to Figure 1. 


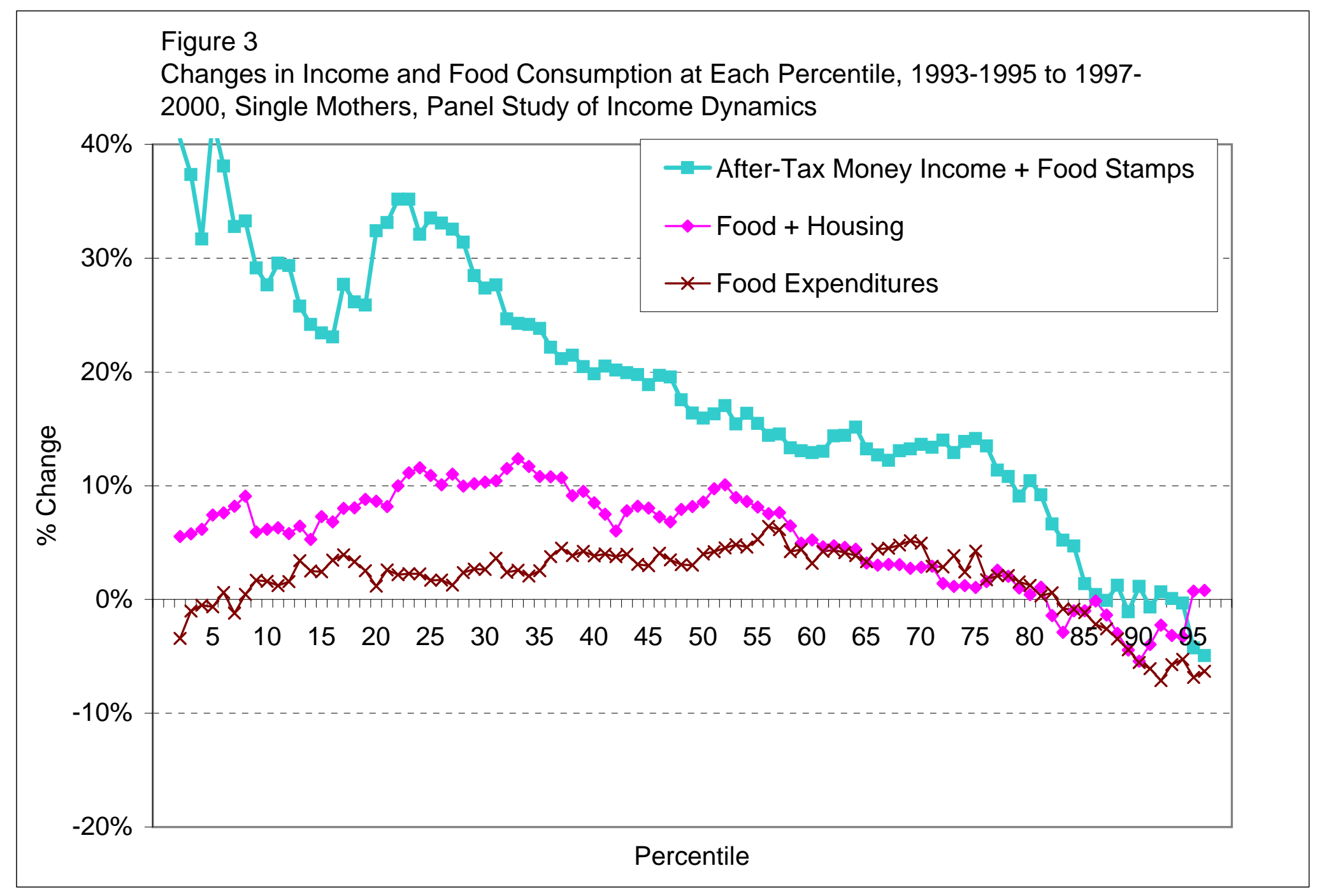

Notes: Data are from the Panel Study of Income Dynamics, waves 1993 through 2001. Housing spending from the PSID includes rent, a service flow from owned property, and the rental equivalent for non-owners that do not pay for housing. The changes are in real terms and outcomes are adjusted for differences in family size. 


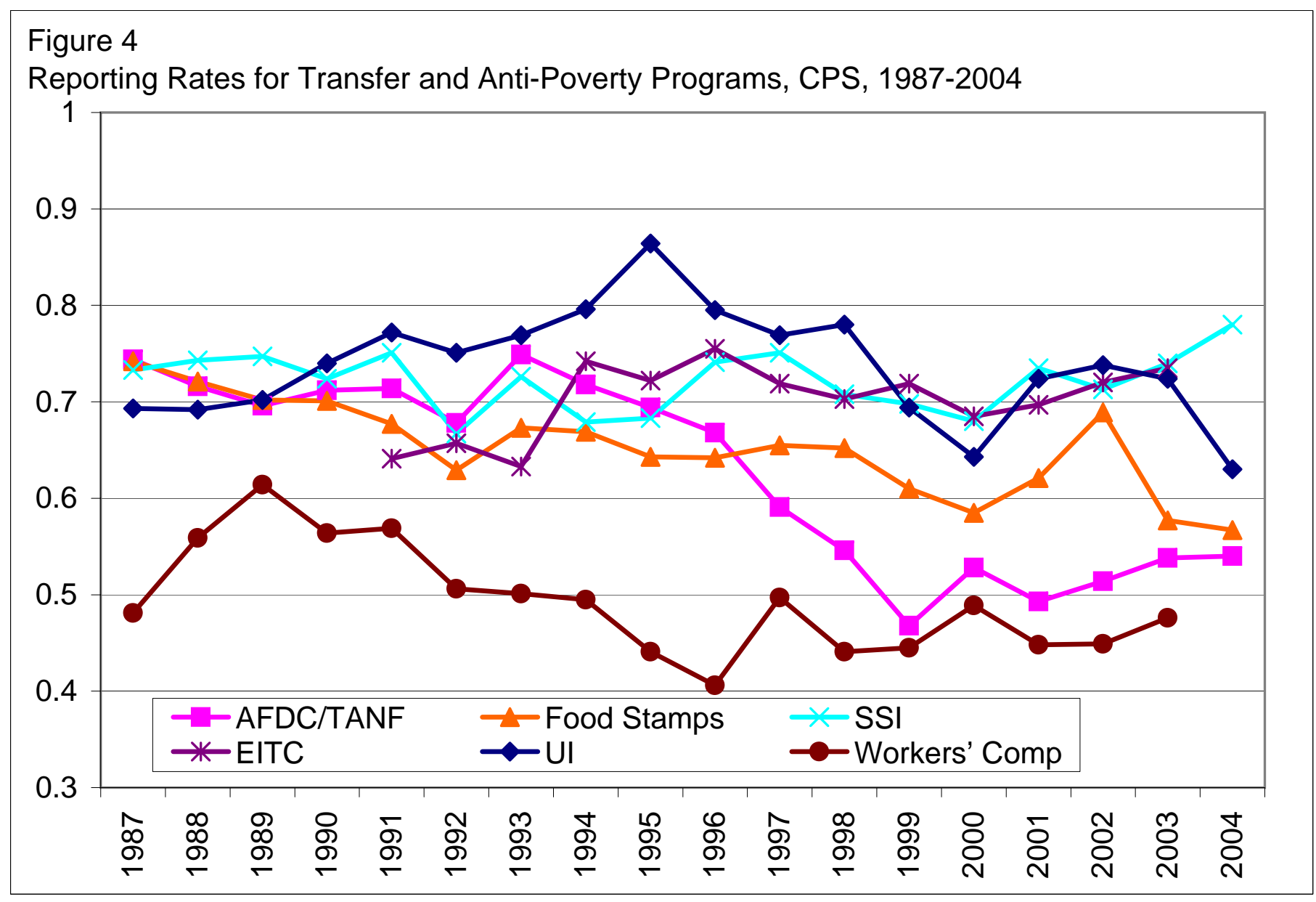

Notes: Data are from Meyer, Mok, \& Sullivan (2007). Reporting rates for each year are calculated as the ratio of the total weighted dollars reported for each program in the CPS divided by the respective administrative aggregate. Sources for administrative numbers are reported in Meyer, Mok, and Sullivan (2007). 
Table 1

Quantile Regressions for Changes in Consumption and Income, Single Mothers and Comparison Groups, Consumer Expenditure Survey, 1993-2003

\begin{tabular}{|c|c|c|c|c|c|c|c|c|}
\hline & \multicolumn{4}{|c|}{ Single Mothers Only } & \multicolumn{2}{|c|}{ Single Women } & \multicolumn{2}{|c|}{ Mothers } \\
\hline & \multicolumn{2}{|c|}{ Consumption } & \multicolumn{2}{|c|}{ Income } & \multirow{2}{*}{$\begin{array}{c}\text { Consumption } \\
(5)\end{array}$} & \multirow{2}{*}{$\begin{array}{c}\text { Income } \\
(6)\end{array}$} & \multirow{2}{*}{$\begin{array}{c}\text { Consumption } \\
(7)\end{array}$} & \multirow{2}{*}{$\frac{\text { Income }}{(8)}$} \\
\hline & (1) & (2) & (3) & (4) & & & & \\
\hline \multicolumn{9}{|l|}{ Quantile Regression: } \\
\hline \multicolumn{9}{|l|}{ 5th Percentile } \\
\hline$(1997-00)-(1993-95)$ & $\begin{array}{c}0.056 \\
(0.047)\end{array}$ & $\begin{array}{c}0.047 \\
(0.044)\end{array}$ & $\begin{array}{l}-0.250 \\
(0.088)\end{array}$ & $\begin{array}{l}-0.190 \\
(0.085)\end{array}$ & $\begin{array}{c}0.104 \\
(0.064)\end{array}$ & $\begin{array}{l}-0.181 \\
(0.156)\end{array}$ & $\begin{array}{c}0.055 \\
(0.057)\end{array}$ & $\begin{array}{l}-0.387 \\
(0.174)\end{array}$ \\
\hline$(2001-03)-(1993-95)$ & $\begin{array}{c}0.050 \\
(0.053)\end{array}$ & $\begin{array}{l}-0.037 \\
(0.046)\end{array}$ & $\begin{array}{l}-0.250 \\
(0.104)\end{array}$ & $\begin{array}{l}-0.188 \\
(0.109)\end{array}$ & $\begin{array}{c}0.114 \\
(0.066)\end{array}$ & $\begin{array}{l}-0.043 \\
(0.179)\end{array}$ & $\begin{array}{c}0.045 \\
(0.060)\end{array}$ & $\begin{array}{l}-0.601 \\
(0.175)\end{array}$ \\
\hline \multicolumn{9}{|l|}{ 10th Percentile } \\
\hline$(1997-00)-(1993-95)$ & $\begin{array}{c}0.086 \\
(0.032)\end{array}$ & $\begin{array}{c}0.066 \\
(0.031)\end{array}$ & $\begin{array}{l}-0.118 \\
(0.060)\end{array}$ & $\begin{array}{l}-0.079 \\
(0.068)\end{array}$ & $\begin{array}{c}0.118 \\
(0.052)\end{array}$ & $\begin{array}{l}-0.079 \\
(0.112)\end{array}$ & $\begin{array}{c}0.085 \\
(0.041)\end{array}$ & $\begin{array}{l}-0.188 \\
(0.090)\end{array}$ \\
\hline$(2001-03)-(1993-95)$ & $\begin{array}{l}0.075 \\
(0.035)\end{array}$ & $\begin{array}{c}0.016 \\
(0.036)\end{array}$ & $\begin{array}{l}-0.084 \\
(0.053)\end{array}$ & $\begin{array}{c}0.002 \\
(0.069)\end{array}$ & $\begin{array}{c}0.151 \\
(0.052)\end{array}$ & $\begin{array}{c}0.090 \\
(0.107)\end{array}$ & $\begin{array}{c}0.084 \\
(0.046)\end{array}$ & $\begin{array}{l}-0.272 \\
(0.090)\end{array}$ \\
\hline \multicolumn{9}{|l|}{ 15th Percentile } \\
\hline$(1997-00)-(1993-95)$ & $\begin{array}{c}0.087 \\
(0.030)\end{array}$ & $\begin{array}{c}0.066 \\
(0.031)\end{array}$ & $\begin{array}{l}-0.018 \\
(0.042)\end{array}$ & $\begin{array}{l}-0.007 \\
(0.054)\end{array}$ & $\begin{array}{c}0.074 \\
(0.041)\end{array}$ & $\begin{array}{l}-0.003 \\
(0.067)\end{array}$ & $\begin{array}{c}0.079 \\
(0.036)\end{array}$ & $\begin{array}{l}-0.110 \\
(0.080)\end{array}$ \\
\hline$(2001-03)-(1993-95)$ & $\begin{array}{c}0.097 \\
(0.032)\end{array}$ & $\begin{array}{c}0.040 \\
(0.032)\end{array}$ & $\begin{array}{l}-0.001 \\
(0.043)\end{array}$ & $\begin{array}{l}-0.001 \\
(0.054)\end{array}$ & $\begin{array}{c}0.096 \\
(0.045)\end{array}$ & $\begin{array}{c}0.095 \\
(0.075)\end{array}$ & $\begin{array}{c}0.108 \\
(0.038)\end{array}$ & $\begin{array}{l}-0.179 \\
(0.086)\end{array}$ \\
\hline \multicolumn{9}{|l|}{ 20th Percentile } \\
\hline$(1997-00)$ - (1993-95) & $\begin{array}{c}0.078 \\
(0.037)\end{array}$ & $\begin{array}{c}0.060 \\
(0.027)\end{array}$ & $\begin{array}{c}0.030 \\
(0.047)\end{array}$ & $\begin{array}{c}0.039 \\
(0.044)\end{array}$ & $\begin{array}{c}0.071 \\
(0.039)\end{array}$ & $\begin{array}{c}0.047 \\
(0.065)\end{array}$ & $\begin{array}{c}0.057 \\
(0.038)\end{array}$ & $\begin{array}{l}-0.081 \\
(0.063)\end{array}$ \\
\hline$(2001-03)-(1993-95)$ & $\begin{array}{c}0.088 \\
(0.036)\end{array}$ & $\begin{array}{c}0.026 \\
(0.027)\end{array}$ & $\begin{array}{c}0.076 \\
(0.053)\end{array}$ & $\begin{array}{c}0.058 \\
(0.044)\end{array}$ & $\begin{array}{c}0.082 \\
(0.044)\end{array}$ & $\begin{array}{c}0.119 \\
(0.068)\end{array}$ & $\begin{array}{c}0.084 \\
(0.038)\end{array}$ & $\begin{array}{l}-0.152 \\
(0.064)\end{array}$ \\
\hline \multicolumn{9}{|l|}{ 25th Percentile } \\
\hline$(1997-00)-(1993-95)$ & $\begin{array}{c}0.074 \\
(0.031)\end{array}$ & $\begin{array}{c}0.050 \\
(0.023)\end{array}$ & $\begin{array}{c}0.079 \\
(0.041)\end{array}$ & $\begin{array}{c}0.040 \\
(0.042)\end{array}$ & $\begin{array}{c}0.030 \\
(0.030)\end{array}$ & $\begin{array}{c}0.026 \\
(0.056)\end{array}$ & $\begin{array}{c}0.045 \\
(0.032)\end{array}$ & $\begin{array}{l}-0.009 \\
(0.068)\end{array}$ \\
\hline$(2001-03)-(1993-95)$ & $\begin{array}{c}0.075 \\
(0.034)\end{array}$ & $\begin{array}{c}0.024 \\
(0.026)\end{array}$ & $\begin{array}{c}0.129 \\
(0.040)\end{array}$ & $\begin{array}{c}0.078 \\
(0.043)\end{array}$ & $\begin{array}{c}0.062 \\
(0.033)\end{array}$ & $\begin{array}{c}0.098 \\
(0.063)\end{array}$ & $\begin{array}{c}0.064 \\
(0.033)\end{array}$ & $\begin{array}{l}-0.082 \\
(0.060)\end{array}$ \\
\hline \multicolumn{9}{|l|}{ 30th Percentile } \\
\hline$(1997-00)-(1993-95)$ & $\begin{array}{c}0.070 \\
(0.030)\end{array}$ & $\begin{array}{c}0.042 \\
(0.024)\end{array}$ & $\begin{array}{c}0.110 \\
(0.038)\end{array}$ & $\begin{array}{c}0.045 \\
(0.043)\end{array}$ & $\begin{array}{c}0.025 \\
(0.030)\end{array}$ & $\begin{array}{c}0.005 \\
(0.052)\end{array}$ & $\begin{array}{c}0.053 \\
(0.032)\end{array}$ & $\begin{array}{c}0.004 \\
(0.056)\end{array}$ \\
\hline$(2001-03)-(1993-95)$ & $\begin{array}{c}0.068 \\
(0.033)\end{array}$ & $\begin{array}{c}0.017 \\
(0.024)\end{array}$ & $\begin{array}{c}0.148 \\
(0.041)\end{array}$ & $\begin{array}{c}0.053 \\
(0.043)\end{array}$ & $\begin{array}{c}0.063 \\
(0.035)\end{array}$ & $\begin{array}{c}0.091 \\
(0.055)\end{array}$ & $\begin{array}{c}0.065 \\
(0.032)\end{array}$ & $\begin{array}{l}-0.084 \\
(0.057)\end{array}$ \\
\hline \multicolumn{9}{|l|}{ 35th Percentile } \\
\hline$(1997-00)-(1993-95)$ & $\begin{array}{c}0.062 \\
(0.036)\end{array}$ & $\begin{array}{c}0.033 \\
(0.024)\end{array}$ & $\begin{array}{c}0.139 \\
(0.034)\end{array}$ & $\begin{array}{c}0.043 \\
(0.037)\end{array}$ & $\begin{array}{c}0.013 \\
(0.029)\end{array}$ & $\begin{array}{c}-0.003 \\
(0.045)\end{array}$ & $\begin{array}{c}0.035 \\
(0.028)\end{array}$ & $\begin{array}{l}-0.025 \\
(0.046)\end{array}$ \\
\hline$(2001-03)-(1993-95)$ & $\begin{array}{c}0.071 \\
(0.038)\end{array}$ & $\begin{array}{c}0.019 \\
(0.024)\end{array}$ & $\begin{array}{c}0.175 \\
(0.040)\end{array}$ & $\begin{array}{c}0.037 \\
(0.037)\end{array}$ & $\begin{array}{c}0.051 \\
(0.029)\end{array}$ & $\begin{array}{c}0.078 \\
(0.055)\end{array}$ & $\begin{array}{c}0.049 \\
(0.029)\end{array}$ & $\begin{array}{l}-0.093 \\
(0.046)\end{array}$ \\
\hline \multicolumn{9}{|l|}{ 40th Percentile } \\
\hline$(1997-00)-(1993-95)$ & $\begin{array}{c}0.045 \\
(0.033)\end{array}$ & $\begin{array}{c}0.041 \\
(0.020)\end{array}$ & $\begin{array}{c}0.153 \\
(0.039)\end{array}$ & $\begin{array}{c}0.030 \\
(0.034)\end{array}$ & $\begin{array}{c}0.011 \\
(0.027)\end{array}$ & $\begin{array}{c}0.017 \\
(0.042)\end{array}$ & $\begin{array}{c}0.023 \\
(0.032)\end{array}$ & $\begin{array}{l}-0.012 \\
(0.043)\end{array}$ \\
\hline$(2001-03)-(1993-95)$ & $\begin{array}{c}0.050 \\
(0.033)\end{array}$ & $\begin{array}{c}0.015 \\
(0.021)\end{array}$ & $\begin{array}{c}0.188 \\
(0.037)\end{array}$ & $\begin{array}{c}0.021 \\
(0.035)\end{array}$ & $\begin{array}{c}0.030 \\
(0.027)\end{array}$ & $\begin{array}{c}0.082 \\
(0.048)\end{array}$ & $\begin{array}{c}0.023 \\
(0.028)\end{array}$ & $\begin{array}{l}-0.091 \\
(0.039)\end{array}$ \\
\hline \multicolumn{9}{|l|}{ 45th Percentile } \\
\hline$(1997-00)-(1993-95)$ & $\begin{array}{c}0.050 \\
(0.033)\end{array}$ & $\begin{array}{c}0.036 \\
(0.022)\end{array}$ & $\begin{array}{c}0.146 \\
(0.051)\end{array}$ & $\begin{array}{c}0.021 \\
(0.032)\end{array}$ & $\begin{array}{c}0.008 \\
(0.029)\end{array}$ & $\begin{array}{c}0.017 \\
(0.043)\end{array}$ & $\begin{array}{c}0.024 \\
(0.030)\end{array}$ & $\begin{array}{l}-0.010 \\
(0.045)\end{array}$ \\
\hline$(2001-03)-(1993-95)$ & $\begin{array}{c}0.042 \\
(0.027)\end{array}$ & $\begin{array}{c}0.006 \\
(0.023)\end{array}$ & $\begin{array}{c}0.166 \\
(0.058)\end{array}$ & $\begin{array}{c}0.023 \\
(0.032)\end{array}$ & $\begin{array}{c}0.022 \\
(0.029)\end{array}$ & $\begin{array}{c}0.080 \\
(0.044)\end{array}$ & $\begin{array}{c}0.025 \\
(0.029)\end{array}$ & $\begin{array}{l}-0.072 \\
(0.044)\end{array}$ \\
\hline \multicolumn{9}{|l|}{ 50th Percentile } \\
\hline$(1997-00)-(1993-95)$ & $\begin{array}{c}0.049 \\
(0.027)\end{array}$ & $\begin{array}{c}0.033 \\
(0.021)\end{array}$ & $\begin{array}{c}0.111 \\
(0.044)\end{array}$ & $\begin{array}{c}0.043 \\
(0.028)\end{array}$ & $\begin{array}{c}0.011 \\
(0.026)\end{array}$ & $\begin{array}{c}0.018 \\
(0.047)\end{array}$ & $\begin{array}{c}0.024 \\
(0.028)\end{array}$ & $\begin{array}{c}0.019 \\
(0.041)\end{array}$ \\
\hline$(2001-03)-(1993-95)$ & $\begin{array}{c}0.024 \\
(0.026)\end{array}$ & $\begin{array}{c}0.000 \\
(0.020)\end{array}$ & $\begin{array}{c}0.144 \\
(0.047)\end{array}$ & $\begin{array}{c}0.052 \\
(0.031)\end{array}$ & $\begin{array}{c}0.015 \\
(0.028)\end{array}$ & $\begin{array}{c}0.062 \\
(0.046)\end{array}$ & $\begin{array}{c}0.021 \\
(0.028)\end{array}$ & $\begin{array}{l}-0.055 \\
(0.043)\end{array}$ \\
\hline $\begin{array}{l}\text { Controls Included } \\
\mathrm{N}\end{array}$ & $\begin{array}{c}\text { No } \\
11,610\end{array}$ & $\begin{array}{c}\text { Yes } \\
11,610\end{array}$ & $\begin{array}{c}\text { No } \\
11,610\end{array}$ & $\begin{array}{c}\text { Yes } \\
11,610\end{array}$ & $\begin{array}{c}\text { Yes } \\
26,368\end{array}$ & $\begin{array}{c}\text { Yes } \\
26,368\end{array}$ & $\begin{array}{c}\text { Yes } \\
26,368\end{array}$ & $\begin{array}{c}\text { Yes } \\
26,368\end{array}$ \\
\hline
\end{tabular}

Notes: Controls include a cubic in the age of the head, number of children less than 18 , number of girls age 2-15, number of boys age $2-15$, education of the head, race, and region. For the models that include married mothers we also include the number of earners in the family and the education of the spouse. Columns 1 through 4 report the coefficients on the 2nd and 3rd period dummies in quantile regressions where the first period dummy is excluded. Columns 5 through 8 report the difference between the coefficients on single mother*period interaction terms. All standard errors are bootstrapped and corrected for within family dependence. See text for more details. 
Table 2

Percentiles of Real Income and Expenditures, CPS and CE Survey, 1993-2003

\begin{tabular}{lcccccc}
\hline & \multicolumn{5}{c}{ Percentiles } \\
& 5th & 10th & 20th & 30th & 40th & 50th \\
\hline $\begin{array}{l}\text { Panel A: All families } \\
\text { Total Family Income (CPS) }\end{array}$ & & & & \\
(1) Percentile of income & 8,151 & 13,890 & 20,655 & 26,749 & 33,149 & 40,048 \\
(2) Mean below given percentile of income & 2,620 & 7,006 & 12,209 & 16,035 & 19,505 & 22,913 \\
Total Family Income (CE) & & & & & & \\
(3) Percentile of income & 7,904 & 12,625 & 18,559 & 23,611 & 29,019 & 35,299 \\
(4) Mean below given percentile of income & 3,441 & 6,943 & 11,351 & 14,596 & 17,515 & 20,430 \\
(5) Mean below given percentile of expenditures & 13,236 & 15,238 & 18,360 & 21,006 & 23,520 & 26,046 \\
Total Family Expenditures (CE) & & & & & & \\
(6) Percentile of expenditures & 11,771 & 15,058 & 20,343 & 25,220 & 30,206 & 35,581 \\
(7) Mean below given percentile of expenditures & 8,550 & 11,016 & 14,392 & 17,190 & 19,812 & 22,418 \\
(8) Mean below given percentile of income & 24,514 & 23,135 & 23,257 & 24,663 & 26,372 & 28,248 \\
\hline Panel B: All single mother headed families & & & & & & \\
Total Family Income (CPS) & & & & & \\
(9) Percentile of income & 3,971 & 7,129 & 10,941 & 14,713 & 18,629 & 22,409 \\
(10) Mean below given percentile of income & 1,260 & 3,470 & 6,299 & 8,465 & 10,525 & 12,530 \\
Total Family Income (CE) & & & & & \\
(11) Percentile of income & 4,774 & 7,103 & 10,786 & 14,136 & 17,873 & 21,240 \\
(12) Mean below given percentile of income & 2,641 & 4,315 & 6,637 & 8,560 & 10,420 & 12,250 \\
(13) Mean below given percentile of expenditures & 9,087 & 9,921 & 11,091 & 12,314 & 13,709 & 15,099 \\
Total Family Expenditures (CE) & & & & & & \\
(14) Percentile of expenditures & 8,496 & 10,532 & 13,707 & 16,710 & 20,221 & 23,676 \\
(15) Mean below given percentile of expenditures & 6,649 & 8,116 & 10,125 & 11,834 & 13,491 & 15,180 \\
(16) Mean below given percentile of income & 17,495 & 16,330 & 15,669 & 16,304 & 17,253 & 18,416 \\
\hline
\end{tabular}

Notes: The samples in Panel B include all unmarried female headed consumer units or families living with at least one child under 18. Expenditures are measured as outlays (following Rogers and Gray, 1994) and income is after tax and includes food stamps as explained in the text. These family level outcomes are expressed in real terms (2005 dollars) and adjusted for differences in family size using the NAS recommended equivalence scale and normalized to a family with one adult and two children. Samples from the CE Survey include only those designated as complete income reporters (U.S. Department of Labor, various years). See text for more details. 


\section{Table 3}

Comparison of CE Survey Expenditure Measures to National Aggregates, 19842004

\begin{tabular}{lcccccc}
\hline & 1984 & 1987 & 1992 & 1997 & 2002 & 2004 \\
\hline Food at home $^{\mathrm{a}}$ & & & & & & \\
$\quad$ CE & 205.1 & 236.4 & 324.9 & 376.2 & 400.2 & 477.4 \\
$\quad$ PCE & 260.6 & 290.7 & 366.8 & 431.3 & 540.1 & 603.4 \\
$\quad$ Ratio & 0.787 & 0.813 & 0.886 & 0.872 & 0.741 & 0.791 \\
Food away from home ${ }^{\mathrm{b}}$ & & & & & & \\
$\quad$ CE & 98.9 & 120.1 & 136.4 & 164.9 & 176.9 & 217.8 \\
$\quad$ PCE & 123.6 & 154.9 & 212.3 & 262.7 & 339.4 & 388.2 \\
$\quad$ Ratio & 0.801 & 0.775 & 0.643 & 0.628 & 0.521 & 0.561 \\
$\quad$ Total food & & & & & & \\
$\quad$ CE & 304.1 & 356.4 & 461.4 & 541.1 & 577.1 & 695.2 \\
$\quad$ PCE & 384.2 & 445.6 & 579.1 & 694.0 & 879.5 & 991.6 \\
$\quad$ Ratio & 0.791 & 0.800 & 0.797 & 0.780 & 0.656 & 0.701 \\
Rent plus Utilities & & & & & & \\
$\quad$ CE & 202.3 & 235.1 & 306.7 & 380.7 & 401.6 & 485.1 \\
$\quad$ PCE & 209.9 & 250.0 & 315.0 & 387.7 & 469.6 & 504.5 \\
$\quad$ Ratio & 0.964 & 0.940 & 0.974 & 0.982 & 0.855 & 0.961 \\
\hline
\end{tabular}

Notes: PCE numbers come from National Income and Product Account Table 2.5.5: Personal Consumption Expenditures by Type of Expenditure.

${ }^{a}$ Food at home is food purchased for off-premise consumption minus alcoholic beverages

${ }^{\mathrm{b}}$ Food away from home is purchased meals and beverages minus other alcoholic beverages.

${ }^{c}$ Rent plus utilities is rent on tenant-occupied nonfarm dwellings plus utilities excluding telephone. 
Table 4

Survey Nonresponse and Imputations Rates, CPS and CE Interview Survey, 1993-2003

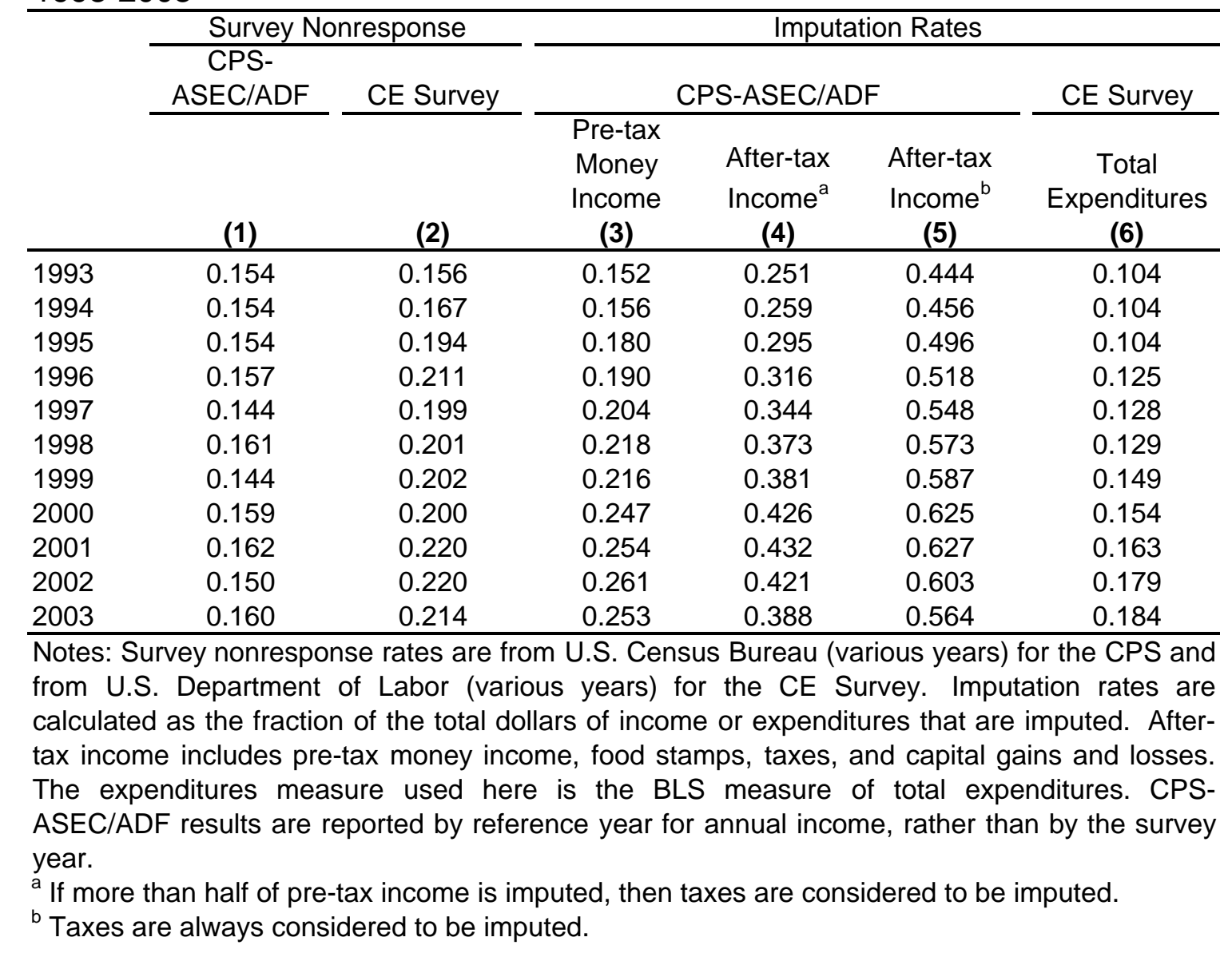


Table 5

OLS Estimates for Consumption and Income, Single Mothers and Comparison Households, High School Degree or Less, CE and PSID $1984-2000$

\begin{tabular}{|c|c|c|c|c|c|c|}
\hline & \multicolumn{3}{|c|}{ Single Women } & \multicolumn{3}{|c|}{ Mothers } \\
\hline & Consumption & Income & $\begin{array}{c}\text { Ratio of Standard } \\
\text { Errors: } \\
(2) /(1) \\
\end{array}$ & Consumption & Income & $\begin{array}{l}\text { Ratio of Standard } \\
\text { Errors: } \\
\text { (5) / (4) }\end{array}$ \\
\hline & (1) & (2) & (3) & (4) & (5) & $(6)$ \\
\hline \multicolumn{7}{|l|}{$\overline{C E}$} \\
\hline \multirow{2}{*}{ Single Mother*1984-1990 } & 0.0744 & 0.0323 & & -0.4311 & -0.6296 & \\
\hline & $(0.0675)$ & $(0.1083)$ & 1.605 & $(0.0234)$ & $(0.0444)$ & 1.899 \\
\hline \multirow[t]{2}{*}{ Single Mother*1991-1993 } & 0.1094 & 0.1235 & & -0.3984 & -0.6041 & \\
\hline & $(0.0696)$ & $(0.1152)$ & 1.655 & $(0.0281)$ & $(0.0523)$ & 1.860 \\
\hline \multirow[t]{2}{*}{ Single Mother*1994-1995 } & 0.1623 & 0.1169 & & -0.3648 & -0.6612 & \\
\hline & $(0.0775)$ & $(0.1340)$ & 1.729 & $(0.0331)$ & $(0.0556)$ & 1.681 \\
\hline \multirow[t]{2}{*}{ Single Mother*1996-2000 } & 0.2021 & 0.1425 & & -0.3253 & -0.6578 & \\
\hline & $(0.0688)$ & $(0.1125)$ & 1.636 & $(0.0250)$ & $(0.0497)$ & 1.986 \\
\hline $\mathbf{N}$ & 17,511 & 14,761 & & 53,457 & 45,434 & \\
\hline $\mathbf{R}^{2}$ & 0.2338 & 0.1545 & & 0.3750 & 0.1963 & \\
\hline Variance of Dependent Variable & 0.3394 & 0.7820 & & 0.2935 & 1.0335 & \\
\hline \multicolumn{7}{|l|}{ PSID } \\
\hline \multirow[t]{2}{*}{ Single Mother*1984-1990 } & 0.3810 & 0.3425 & & -0.2954 & -0.5549 & \\
\hline & $(0.0880)$ & $(0.1492)$ & 1.696 & $(0.0287)$ & $(0.0623)$ & 2.170 \\
\hline \multirow[t]{2}{*}{ Single Mother*1991-1993 } & 0.3902 & 0.2285 & & -0.2033 & -0.7395 & \\
\hline & $(0.0843)$ & $(0.1542)$ & 1.828 & $(0.0307)$ & $(0.0672)$ & 2.188 \\
\hline \multirow[t]{2}{*}{ Single Mother*1994-1995 } & 0.3849 & 0.6207 & & -0.1742 & -0.5538 & \\
\hline & $(0.0963)$ & $(0.2098)$ & 2.177 & $(0.0368)$ & $(0.0564)$ & 1.533 \\
\hline \multirow[t]{2}{*}{ Single Mother*1996-1999 } & 0.4304 & 0.2846 & & -0.1919 & -0.5410 & \\
\hline & $(0.0943)$ & $(0.1702)$ & 1.805 & $(0.0290)$ & $(0.0689)$ & 2.374 \\
\hline $\mathbf{N}$ & 6,952 & 6,415 & & 18,965 & 17,233 & \\
\hline $\mathbf{R}^{2}$ & 0.2661 & 0.1367 & & 0.2943 & 0.2853 & \\
\hline Variance of Dependent Variable & 0.3348 & 1.5504 & & 0.2293 & 1.1548 & \\
\hline
\end{tabular}


Table 6

Percentiles of Consumption for Various Samples, CE Survey, 1993-2003

\begin{tabular}{|c|c|c|c|c|c|c|}
\hline & \multicolumn{6}{|c|}{ Percentiles } \\
\hline & 5th & 10th & 20th & 30th & 40th & 50th \\
\hline \multicolumn{7}{|l|}{ All families } \\
\hline (1) Consumption --excluding incomplete income reporters & 12,484 & 15,617 & 20,336 & 24,453 & 28,465 & 32,695 \\
\hline (2) Consumption --including incomplete income reporters & 12,307 & 15,450 & 20,078 & 24,100 & 28,038 & 32,168 \\
\hline (3) Consumption --second quarter interviews only & 12,383 & 15,562 & 20,190 & 24,203 & 28,197 & 32,352 \\
\hline $\begin{array}{l}\text { (4) Consumption --first reported interview for each CU } \\
\text { All sinale mother headed families }\end{array}$ & 11,350 & 14,540 & 19,264 & 23,311 & 27,292 & 31,455 \\
\hline (1) Consumption --excluding incomplete income reporters & 9,516 & 11,361 & 14,125 & 16,761 & 19,480 & 22,321 \\
\hline (2) Consumption --including incomplete income reporters & 9,230 & 11,109 & 13,823 & 16,358 & 18,985 & 21,803 \\
\hline (3) Consumption --second quarter interviews only & 9,368 & 11,306 & 14,282 & 16,888 & 19,418 & 22,334 \\
\hline (4) Consumption --first reported interview for each CU & 8,814 & 10,656 & 13,531 & 16,075 & 18,719 & 21,573 \\
\hline \multicolumn{7}{|l|}{ All families with head 65 or over } \\
\hline (1) Consumption --excluding incomplete income reporters & 13,211 & 15,977 & 20,084 & 23,754 & 27,273 & 31,097 \\
\hline (2) Consumption --including incomplete income reporters & 13,261 & 16,008 & 20,054 & 23,642 & 27,096 & 30,870 \\
\hline (3) Consumption --second quarter interviews only & 13,284 & 15,979 & 20,027 & 23,617 & 27,097 & 30,890 \\
\hline (4) Consumption --first reported interview for each CU & 13,107 & 15,832 & 19,863 & 23,437 & 26,874 & 30,692 \\
\hline \multicolumn{7}{|l|}{ All families with head that is disabled } \\
\hline (1) Consumption --excluding incomplete income reporters & 9,784 & 11,636 & 14,293 & 16,710 & 19,055 & 21,658 \\
\hline (2) Consumption --including incomplete income reporters & 9,732 & 11,683 & 14,433 & 16,936 & 19,280 & 21,975 \\
\hline (3) Consumption --second quarter interviews only & 9,720 & 11,753 & 14,492 & 17,024 & 19,586 & 22,244 \\
\hline (4) Consumption --first reported interview for each CU & 9,147 & 11,219 & 14,247 & 16,738 & 19,232 & 21,955 \\
\hline
\end{tabular}

Notes: Single mother headed families include all consumer units (CUs) headed by an unmarried female who lives with at least one child under the age of 18. The disabled sample includes all CUs with a head who did not work in the previous year due to a disability. We use the BLS designation of complete income reporters (see U.S. Department of Labor, various years). Rows 3 and 4 do not exclude incomplete income reporters. Row 3 in each panel includes data from second quarter interviews only, which is the first quarter that the living unit is eligible to report complete expenditure data. Following Bavier (2007), Row 4 in each panel includes all CUs reporting complete expenditure data for the first time, which will include multiple responses from the same living unit if different CUs reside in the living unit while the living unit is in the survey. See the notes to Table 2 for additional details. 
Table 7

Relative Outcomes for the Bottom Five Percent of Income and Consumption, All Families, CE Survey and PSID

\begin{tabular}{|c|c|c|c|c|c|c|c|}
\hline \multirow[t]{2}{*}{ Outcome } & \multicolumn{3}{|c|}{ Percentiles of Income } & \multicolumn{3}{|c|}{ Percentiles of Consumption } & \multirow[b]{2}{*}{ Diff in Diff } \\
\hline & $0-5$ & $5-100$ & Difference & $0-5$ & $5-100$ & Difference & \\
\hline & (1) & $(2)$ & $(3)=(1)-(2)$ & (4) & (5) & $(6)=(4)-(5)$ & $(7)=(6)-(3)$ \\
\hline \multicolumn{8}{|l|}{ CE, 1991-1998 } \\
\hline Have a stove in residence & 0.885 & 0.989 & -0.104 & 0.870 & 0.990 & -0.119 & -0.016 \\
\hline Have a microwave in residence & 0.688 & 0.883 & -0.195 & 0.597 & 0.887 & -0.291 & $-0.096^{*}$ \\
\hline Have a refrigerator in residence & 0.957 & 0.993 & -0.036 & 0.949 & 0.993 & -0.044 & -0.008 \\
\hline Have a freezer in residence & 0.217 & 0.325 & -0.108 & 0.159 & 0.328 & -0.169 & $-0.061^{*}$ \\
\hline Have a disposal in residence & 0.264 & 0.428 & -0.164 & 0.149 & 0.434 & -0.286 & $-0.122^{\star}$ \\
\hline Have a dish washer in residence & 0.313 & 0.561 & -0.248 & 0.135 & 0.570 & -0.435 & $-0.187^{*}$ \\
\hline Have a clothes washer in residence & 0.528 & 0.785 & -0.257 & 0.424 & 0.791 & -0.366 & $-0.109 *$ \\
\hline Have a clothes dryer in residence & 0.448 & 0.745 & -0.297 & 0.306 & 0.752 & -0.446 & $-0.149^{*}$ \\
\hline Have a color television in residence & 0.887 & 0.975 & -0.088 & 0.871 & 0.976 & -0.105 & $-0.017^{\star}$ \\
\hline Have a computer in residence & 0.312 & 0.424 & -0.112 & 0.175 & 0.431 & -0.256 & $-0.143^{\star}$ \\
\hline Have a stereo in residence & 0.573 & 0.678 & -0.105 & 0.468 & 0.683 & -0.215 & $-0.110^{*}$ \\
\hline Have a vcr in residence & 0.639 & 0.830 & -0.191 & 0.518 & 0.836 & -0.318 & $-0.127^{\star}$ \\
\hline Have central air conditioning & 0.321 & 0.499 & -0.178 & 0.207 & 0.505 & -0.298 & $-0.120^{\star}$ \\
\hline Total \# of rooms in residence (scaled) & 5.947 & 6.576 & -0.628 & 4.552 & 6.638 & -2.086 & $-1.458^{\star}$ \\
\hline Have a car & 0.617 & 0.876 & -0.259 & 0.472 & 0.884 & -0.411 & $-0.152^{*}$ \\
\hline Average number of cars & 1.088 & 1.964 & -0.876 & 0.707 & 1.984 & -1.277 & $-0.401^{*}$ \\
\hline Took a trip or vacation & 0.222 & 0.314 & -0.092 & 0.109 & 0.320 & -0.212 & $-0.120^{*}$ \\
\hline Took an overnight trip or vacation & 0.199 & 0.282 & -0.083 & 0.094 & 0.287 & -0.193 & $-0.111^{*}$ \\
\hline Did not receive free food & 0.962 & 0.986 & -0.024 & 0.941 & 0.987 & -0.045 & -0.022 \\
\hline \multicolumn{8}{|l|}{ PSID, 1984-2003 } \\
\hline Total \# of rooms in residence (scaled) & 5.293 & 6.419 & -1.125 & 4.638 & 6.452 & -1.814 & $-0.689^{*}$ \\
\hline Have central air conditioning & 0.328 & 0.491 & -0.164 & 0.289 & 0.493 & -0.204 & $-0.040^{*}$ \\
\hline Have a car & 0.530 & 0.905 & -0.375 & 0.668 & 0.898 & -0.229 & $0.145^{\star}$ \\
\hline Average number of cars & 0.841 & 1.707 & -0.866 & 1.043 & 1.697 & -0.654 & $0.212^{*}$ \\
\hline Mother does not report poor health & 0.904 & 0.962 & -0.058 & 0.894 & 0.963 & -0.069 & -0.011 \\
\hline Health does not limit mothers work & 0.742 & 0.824 & -0.082 & 0.696 & 0.826 & -0.131 & $-0.049 *$ \\
\hline No other family members in bad health & 0.950 & 0.959 & -0.009 & 0.931 & 0.960 & -0.029 & -0.020 \\
\hline Not food insecure & 0.760 & 0.929 & -0.170 & 0.775 & 0.928 & -0.153 & 0.016 \\
\hline Did not go hungry & 0.950 & 0.981 & -0.030 & 0.919 & 0.982 & -0.063 & -0.033 \\
\hline Have no children in poor health & 0.994 & 0.995 & -0.002 & 0.987 & 0.996 & -0.009 & $-0.008^{*}$ \\
\hline
\end{tabular}

Notes: Number of rooms is adjusted for family size using the NAS recommended equivalence scale. PSID data are from various waves between 1984 and 2003 depending on the availability of outcome variables. We predict total consumption in the PSID based on reported values in the PSID for food and housing, and housing flows for homeowners are calculated from reported housing values. We also impute a value of housing for those in public or subsidized housing. This approach is a slightly updated version of that used in Meyer \& Sullivan (2003). * denotes significance at the $5 \%$ level, which is determined using bootstrapped standard errors that correct for within family dependence. 
Table 8

Summary of the Number of Relative Outcomes that Favor Income or Consumption, CE Survey and PSID

\begin{tabular}{|c|c|c|c|c|}
\hline & $\begin{array}{l}\text { Number } \\
\text { Favoring } \\
\text { Income }\end{array}$ & $\begin{array}{c}\text { Number } \\
\text { Significantly } \\
\text { Favoring } \\
\text { Income }\end{array}$ & $\begin{array}{c}\text { Number } \\
\text { Favoring } \\
\text { Consumption }\end{array}$ & $\begin{array}{c}\text { Number } \\
\text { Significantly } \\
\text { Favoring } \\
\text { Consumption }\end{array}$ \\
\hline & (1) & $(2)$ & (3) & $(4)$ \\
\hline \multicolumn{5}{|l|}{ CE Survey (19 Outcomes) } \\
\hline \multicolumn{5}{|l|}{ All single mother headed families } \\
\hline Comparing bottom $5 \%$ to top $95 \%$ & 0 & 0 & 19 & 16 \\
\hline Comparing bottom $10 \%$ to top $90 \%$ & 0 & 0 & 19 & 15 \\
\hline \multicolumn{5}{|l|}{ All families with head 65 or over } \\
\hline Comparing bottom $5 \%$ to top $95 \%$ & 1 & 0 & 18 & 17 \\
\hline Comparing bottom $10 \%$ to top $90 \%$ & 0 & 0 & 19 & 17 \\
\hline \multicolumn{5}{|l|}{ All families with head that is disabled } \\
\hline Comparing bottom $5 \%$ to top $95 \%$ & 7 & 1 & 12 & 7 \\
\hline Comparing bottom $10 \%$ to top $90 \%$ & 2 & 0 & 17 & 12 \\
\hline \multicolumn{5}{|l|}{ PSID (10 Outcomes) } \\
\hline \multicolumn{5}{|l|}{ All single mother headed families } \\
\hline Comparing bottom $5 \%$ to top $95 \%$ & 2 & 0 & 8 & 2 \\
\hline Comparing bottom $10 \%$ to top $90 \%$ & 3 & 1 & 7 & 0 \\
\hline \multicolumn{5}{|l|}{ All families with head 65 or over } \\
\hline Comparing bottom $5 \%$ to top $95 \%$ & 3 & 0 & 7 & 1 \\
\hline Comparing bottom $10 \%$ to top $90 \%$ & 5 & 3 & 5 & 1 \\
\hline \multicolumn{5}{|l|}{ All families with head that is disabled } \\
\hline Comparing bottom $5 \%$ to top $95 \%$ & 2 & 0 & 8 & 0 \\
\hline Comparing bottom $10 \%$ to top $90 \%$ & 5 & 0 & 5 & 0 \\
\hline
\end{tabular}

Notes: The outcomes summarized here are the same as those listed in Table 7 . Columns 2 and 4 refer to statistical significance at the $5 \%$ level. See the notes to Table 6 for sample definitions and the notes to Table 7 for additional details. 
Table A.1

Annual Expenditures and Annualized Quarterly Expenditures, CE Survey 1998-2000

\begin{tabular}{|c|c|c|c|c|c|c|}
\hline & $\begin{array}{c}\text { Annual } \\
\text { Expenditures }\end{array}$ & $\begin{array}{c}\text { Annualized } \\
\text { Quarterly } \\
\text { Expenditures }\end{array}$ & Ratio & $\begin{array}{c}\text { Annual } \\
\text { Consumption }\end{array}$ & $\begin{array}{c}\text { Annualized } \\
\text { Quarterly } \\
\text { Consumption }\end{array}$ & Ratio \\
\hline & (1) & $(2)$ & $(3)=(2) /(1)$ & (4) & (5) & $(6)=(5) /(4)$ \\
\hline \multicolumn{7}{|l|}{ All Families } \\
\hline Mean & 48,606 & 48,604 & 1.000 & 30,692 & 30,662 & 0.999 \\
\hline Standard Deviation & 45,373 & 53,312 & 1.175 & 18,910 & 20,779 & 1.099 \\
\hline $\mathrm{N}$ & 10,938 & 43,752 & 4.000 & 10,771 & 43,084 & 4.000 \\
\hline 5th Percentile & 8,307 & 7,477 & 0.900 & 9,765 & 9,092 & 0.900 \\
\hline 10th Percentile & 11,313 & 10,259 & 0.907 & 12,574 & 11,917 & 0.907 \\
\hline 20th Percentile & 16,497 & 15,312 & 0.928 & 16,655 & 16,159 & 0.928 \\
\hline 30th Percentile & 21,999 & 20,381 & 0.926 & 20,285 & 19,756 & 0.926 \\
\hline 40th Percentile & 28,220 & 26,060 & 0.923 & 23,721 & 23,221 & 0.923 \\
\hline 50th Percentile & 35,490 & 32,992 & 0.930 & 27,302 & 26,688 & 0.930 \\
\hline 60th Percentile & 44,519 & 41,441 & 0.931 & 31,242 & 30,885 & 0.931 \\
\hline 70th Percentile & 55,873 & 52,510 & 0.940 & 36,089 & 35,767 & 0.940 \\
\hline 80th Percentile & 73,168 & 69,744 & 0.953 & 42,073 & 42,101 & 0.953 \\
\hline 90th Percentile & 102,734 & 102,456 & 0.997 & 52,082 & 52,819 & 0.997 \\
\hline 95th Percentile & 131,529 & 141,700 & 1.077 & 61,917 & 64,065 & 1.077 \\
\hline \multicolumn{7}{|c|}{ Single Mother Families } \\
\hline Mean & 36,184 & 36,129 & 0.998 & 22,598 & 22,637 & 1.002 \\
\hline Standard Deviation & 28,789 & 34,339 & 1.193 & 11,841 & 12,746 & 1.076 \\
\hline $\mathrm{N}$ & 429 & 1,716 & 4.000 & 426 & 1,704 & 4.000 \\
\hline 5th Percentile & 8,114 & 7,207 & 0.888 & 8,241 & 7,769 & 0.943 \\
\hline 10th Percentile & 10,864 & 9,605 & 0.884 & 10,165 & 9,816 & 0.966 \\
\hline 20th Percentile & 14,182 & 13,455 & 0.949 & 13,149 & 12,468 & 0.948 \\
\hline 30th Percentile & 19,406 & 17,987 & 0.927 & 15,206 & 14,838 & 0.976 \\
\hline 40th Percentile & 24,399 & 22,079 & 0.905 & 17,655 & 17,217 & 0.975 \\
\hline 50th Percentile & 28,660 & 26,350 & 0.919 & 19,836 & 19,557 & 0.986 \\
\hline 60th Percentile & 33,762 & 32,867 & 0.974 & 22,118 & 22,362 & 1.011 \\
\hline 70th Percentile & 42,258 & 39,918 & 0.945 & 25,668 & 25,973 & 1.012 \\
\hline 80th Percentile & 50,729 & 49,640 & 0.979 & 30,963 & 31,739 & 1.025 \\
\hline 90th Percentile & 73,770 & 68,082 & 0.923 & 38,804 & 39,072 & 1.007 \\
\hline 95th Percentile & 94,584 & 97,279 & 1.028 & 45,389 & 48,013 & 1.058 \\
\hline
\end{tabular}

Notes: Samples include consumer units that remain in the survey for all four quarters. The single mother samples include only lone single mothers. 